\title{
İbretnüma-yı Devlet Adlı Eserin Yazarı Mustafa Kesbî midir? XVIII. Yüzyılın Bilinmeyen Bir Tarihçisi Üzerine Notlar
}

\section{Who is Mustafa Kesbî, the Author of İbretnüma-yi Devlet? Notes on an Unknown Historian of the $18^{\text {th }}$ Century}

\author{
Feridun M. Emecen* [0
}

"Prof. Dr., 29 Mayıs Üniversitesi, Edebiyat Fakültesi, Tarih Bölümü, İstanbul, Türkiye

\section{ORCID: F.M.E. 0000-0002-7478-7411}

Sorumlu yazar/Corresponding author: Feridun M. Emecen,

29 Mayıs Üniversitesi, Edebiyat Fakültesi,

Tarih Bölümü, İstanbul, Türkiye

E-posta/E-mail: feridunemecen@yahoo.com

Başvuru/Submitted: 15.05 .2020

Revizyon Talebi/Revision Requested:

04.06.2020

Son Revizyon/Last Revision Received:

03.07.2020

Kabul/Accepted: 13.07 .2020

\section{Atıf/Citation:}

Emecen, Feridun. "ibretnüma-yı Devlet Adlı. Eserin Yazarı Mustafa Kesbî midir? XVIII. Yüzyılın Bilinmeyen Bir Tarihçisi Üzerine Notlar." Tarih Dergisi - Turkish Journal of History, 71 (2020): 197-221.

https://doi.org/10.26650/TurkJHist.2020.012

\section{öz}

XVIII. yüzyılın ikinci yarısında vücuda getirilen önemli tarihlerden birini teşkil eden ve bu dönem için sıklıkla kullanılan Ibretnüma-yı Devlet adlı eserin yazarı olarak Mustafa Kesbî Efendi gösterilir. Mustafa Kesbî'nin kimliği hakkında ise ayrıntılı bilgilere ulaşılamamıştır. Yazar hakkındaki bilgiler daha çok eserinde kendisine dair kaydettiği notlardan hareketle verilmiş gözükmektedir. Bununla birlikte Mustafa Kesbî adlı birinin var olup olmadığı meselesi de tartışmalı bir mahiyet arz eder. Eserlerinde Kesbî mahlasını kullanan yazar hiçbir yerde adını Mustafa olarak açıklamamakta, bazı geç tarihli kataloglarda ve tezkirelerde görülen Kesbî mahlaslı Mehmed ve Mustafa adlı iki kişi arasında birinin, kuvvetli intimalle de Mustafa'nın İbretnüma'nın müellifi olduğu ileri sürülmektedir. Binaenaleyh ibretnüma-yı Devlet adlı eserin yazarının Mustafa Kesbî olduğuna dair literatürde tartışmasız bir ön kabul söz konusudur. Fakat aynı döneme ait farklı eserlerde yer alan ve gözden kaçtığı anlaşılan bazı bilgiler bu eserin yazarının Kesbî mahlasını kullanan Mehmed Haşim Efendi olduğunu göstermiştir. Mehmed Haşim Efendi, sadece İbretnüma değil o dönemde yazarlarının adları meçhul kalan veya tesbit edilemeyen başka vekayi derlemelerinin de sahibidir. Bu makalede Mehmed Haşim Efendi'nin kimliği ve hangi eserleri kaleme almış olduğu konusundaki tesbitlerin ayrıntıları ortaya konmuştur.

Anahtar sözcükler: Mehmed Haşim Efendi, Kesbî Mehmed, İbretnüma, Kesbî Mustafa, XVIII. yüzyıl tarihçiliği

\section{ABSTRACT}

Mustafa Kesbî Efendi is known as the author of ibretnüma-yı Devlet, which is an important work written in the second half of the $18^{\text {th }}$ century and an oftenused source for this period. However, there is no detailed information about the identity of Mustafa Kesbî Efendi. Information about this author is usually derived from the anecdotes written about himself in the above-mentioned work. Nonetheless, it is also a topic of discussion whether there really was a man called Mustafa Kesbî. Kesbî is a pseudonym used in this work and nowhere in it, is the name Mustafa is to be found. Some later written works, 
such as catalogues and tezkires (collection of biographies) point to two different men with the pseudonym Kesbî: one is Mustafa, the other is Mehmed. These works propound that the author of ibretnüma is most probably Mustafa Kesbî; therefore, the author of this work is doubtlessly Mustafa Kesbî. However, some other contemporary works propose that the author of Ibretnüma is actually Mehmed Haşim Efendi who uses the pseudonym, Kesbî. He is not only the author of Ibretnüma, but he is also the author of some apocryphalness chronicles. This article reveals the identity of Mehmed Haşim Efendi and recognizes in detail his other unknown works.

Keywords: Mehmed Haşim Efendi, Kesbî Mehmed, İbretnüma, Kesbî Mustafa, historians of $18^{\text {th }}$ century

\section{Giriş}

XVIII. yüzyılın siyaset sahnesinde, belirli bir durgunluk dönemi sonrası 1768'de başlayan Osmanlı-Rus savaşı hem askeri hem de sosyal açıdan çok önemli gelişmelerin kaynağını oluşturur. Askeri başarısızlıklarla, bunun getirdiği büyük sıkıntı ve hayal kırıklıklarıyla, merkez dışında meydana gelen çeşitli olaylarla tezahür eden gelişmeleri kaleme alan ve bunları gelecek nesillere "ders alınması” beklentisi içinde aktarmayı amaçlayan münevver kesim içinde bilhassa bürokrasiden yetişme kitabet zümresi öne çıkmış görünür. Seferlere katılan, gelişen hadiseleri ve türlü olumsuzlukları bizzat gören ve aynı zamanda içinde bulundukları dönemin sosyal/psikolojik ağırlığını taşıyan kitabet ehli, sadece kendi gözlemlerini değil çeşitli resmi evrakı, takrirleri ve muhtelif toplantı zabıtlarını da derleyip bazıları mecmua tarzında bazıları vekayiname türünde eserler ortaya koymuşlardır. Tabii ki bu tür derlemelerin veya kronik, hatta bazıları günlük tarzına dönüşen eserlerin yanında resmi tarihçiler olarak vak'anüvislerin “vekayinameleri” ayrı mecrada devamlılık arz edecek derecede mevcudiyetini "güçlü bir şekilde" korumuştur. Fakat kâtiplerin kaleminden çıkma irili ufaklı türlü şekillerde oluşturulmuş olan tarihler, tarihçeler, mecmualar, hatta ruzname kılıklı eserler tamamlayıcı yönleri itibarıyla o dönemin havasını, entelektüel düzeyini, fikriyatını ve zihin dünyasını yansıtacak raddelerde, ihmal edilmemesi gereken bir kaynak külliyatı teşkil eder. Mustafa Kesbî’ye atfedilen İbretnüma-yı Devlet adlı eser de -adının açık şekilde ortaya koyacağı gibi- bu anlamda döneminin önemli kaynakları arasında yer almış, kendisinden sonraki tarihçilerin sıklıkla müracaat ettiği mehazların başında gelmiştir. Burada bu eserin tarihçiliğe katkıları ve ne gibi bir yeri haiz olduğu noktasını bir tarafa bırakarak tamamıyla bu son derece mühim eseri yazan müellifin tarihi kimliğine odaklanmak istemekteyiz.

\section{Kesbî Mustafa ve İbretnüma}

İbretnüma başlığı altında birkaç yazma nüshası bugüne ulaşan eserlerden bazılarının yazarı olarak tanıtılan Mustafa Kesbî hakkında hem adını hem de kendisini açıklığa kavuşturacak tatminkâr biyografik bilgiler yoktur. XIX. yüzyılın sonlarına ait bazı bibliyografik eserlerde çok kısa atıflar yer alır, genellikle de "ketebe-i devletten" olduğu yani kâtib zümresine mensup bulunduğu ve İbretnüma-yı Devlet adlı mecmua kılıklı 1182 (1768) Rusya seferini 
"mübeyyin" kısa bir tarihçe kaleme aldığı bilgisiyle yetinilir. Bu bilgiye Edirneli olduğu da eklenmiştir'. Onun eserini kullanan Ahmed Cevdet Paşa ise yine İbretnüma'yı 1182 seferini ve Kırım Hanlığının ahvalini anlatan bir eser olarak tanımlayıp yazarını "ketebe-i aklâmdan” Kesbî diye tarif eder, 1213 (1798) tarihinde yazılmış mecmua kılıklı bir eser olduğunu bildirir². Kolayca anlaşılacağı üzere Cevdet Paşa doğru bir şekilde eseri sadece Kesbî mahlaslı bir zata atfetmişken daha sonra bu mahlasın yanına Mustafa ismi eklenmiştir ${ }^{3}$. Gerçekten de Íbretnüma nüshalarında sadece müellif olarak Kesbî ismine rastlanır, metin içinde hiçbir yerde Mustafa adı geçmez.

İbretnüma-yı Devlet üzerine yapılan ve daha sonra basılan bir doktora çalışmasına esas teşkil eden iki İbretnüma nüshasında da müellif kendisinden bahsettiği yerlerde ismini vermediği halde bu nüshalar içinde Millet Kütüphanesi Ali Emiri kitapları arasında yer alan yazmanın kapak sayfasının üst kısmında eserin adı yanında yazarı Kesbî Mustafa diye kaydedilmiştir. Muhtemelen buradan hareketle eserin müellifi Mustafa Kesbî olarak belirlenmiştir. İlgili doktora çalışmasında da bu ön kabulle onun Mustafa Kesbî şeklinde tanıtılması sürdürülmüştür. Kesbî dışında müellifin adı hakkında herhangi bir karine bulunmayan nüshaları karşılaştırmalı şekilde yayımlayan nâşir, daimi olarak müellifi Kesbî Mustafa adıyla göstermiş, ayrıca kimliği konusunda literatürü inceleyerek mevcut bilgileri toplamışsa da "Mustafa Kesbî" adıyla irtibatlı kayıtların peşine düştüğünden bu konuda herhangi bir malumata erişememiştir. Onun hakkında daha çok İbretnüma nüshalarına dayalı şekilde yeni bilgiler vermiştir ${ }^{4}$ Nâşire göre Kesbî ile ilişkilendirilebilecek olan iki İbretnüma nüshası ile bir de Divan vardır ${ }^{5}$. Bir başka eser olan İbretnüma-yı Devlet-i

1 Bursalı Mehmed Tahir, Osmanlı Müellifleri, III, İstanbul 1342, s. 131.

2 Ahmed Cevdet Paşa, Tarih-i Cevdet, haz. M. İş̧irli, I, Ankara 2018, s. 6.

3 Osmanlı Müellifleri'nde onun Edirneli Mustafa Kesbî şeklinde tanıtılmış olması, Rif'at Osman'ın Edirne Rehnümâsı 863-1327 Seneleri, Edirne 1336, s. 109'dan kaynaklanmış olabilir. Ahmed Badi, Riyâz-ı Belde-i Edirne, haz. N. Adıgüzel-R. Gündoğdu, II/2, İstanbul 2014, s. 1613 ve 1833 'te Kesbî Mustafa'y1 şair ve hattat olarak tanıtıp divanı olduğunu ve 1212'den (1797) sonra vefat etmiş olabileceğini yazar. Babinger de iki Kesbî'den bahsedip Mustafa'nın Edirneli olduğunu, Mehmed'in ise 1641'de vefat eden bir şair olması hasebiyle bu ikisinin karıştırılmaması gerektiğini, Mustafa Kesbî’nin İbretnüma müellifi bulunduğunu belirtmiştir (Osmanlı Tarih Yazarlarl ve Eserleri, trc. C. Üçok, Mersin 1992, s. 325).

4 Mustafa Kesbî, İbretnümâ-yı Devlet (Tahlil ve Tenkitli Metin), haz. A. Öğreten, Ankara 2002, s. XIII-XVII. Burada bibliyografik ve ansiklopedik bilgiler toplandığı için bunların tekrar tadadına gerek görülmedi. Ayrıca nâşir Kesbî’nin hayatı ve eserlerini daha metodolojik olarak da kaleme almıştır: A. Öğreten, "Kesbî Mustafa Efendi", DIA, XXV, 306-307.

5 İbretnüma'nın iki nüshasından biri İstanbul Millet Kütüphanesi, Ali Emiri kitapları (Tarih, nr. 484) içinde, ötekisi ise İstanbul Üniversitesi Kütüphanesi Yazma Eserler (nr. TY. 5943) kısmında bulunmaktadır. Bu son nüsha kütüphane kataloglarında Cavid adına kayıtlıdır. Ancak her iki eser de derleme niteliğindedir, İlk nüshanın sonunda 1821 Yunan isyanı konusunda bir başka metin yer alır. A. Öğreten'e göre bu kısım yarım kalan eserin boş sayfalarına sonradan sokuşturulmuş olmalıdır. İkinci nüshanın Cavid adına kayıtlı olması ise tamamen hatalı bir adlandırmanın sonucudur (İbretnüma-yı Devlet, giriş kısmı, s. XXVII-XXXI). Kesbî’ye aid Divan İstanbul Üniversitesi Kütüphanesi, nr. TY. 838'de kayıtlıdır. Bu divan üzerinde yüksek lisans çalışması yapılmıştır: Divançe-i Kesbî: Transkripsiyon, Metin, Sözlük, Indeks, haz. Zehra Karakaş, Dumlupınar Üniv. Sosyal Bilimler Enstitüsü, Kütahya 2000; ayrıca İbretnüma-yı Devlet, giriş kısmı, s. XVI; keza bk. ileride not 84). 
Cavid adlı nüshanın Kesbî’nin yazdıklarıyla benzerlikleri varsa da bu ayrı bir eser gibi gözükmektedir ${ }^{6}$.

Bütün bu bilgiler, ön kabullü bir Mustafa Kesbî adını ortaya çıkarmakta ve ona mal edilen eserler üzerinde durulmakta; fakat bu araştırmaların hiçbirinde Kesbî unvanlı olarak kendisini belirten şahsın Mustafa adını gerçekten taşıyıp taşımadığı sorgulanmamakta, hayatının safhaları da ilgili araştırmadaki bilgiler temelli olarak yaygınlaşmış bulunmaktadır ${ }^{7}$. Oysa Kesbî unvanlı şahsın Mustafa adını taşımadığı ve müellifin başka birisi olduğu, Kesbî’ye ait yukarıda belirtilenler dışında bir başka mecmuadaki bilgilerden açık şekilde ortaya çıkmakta ve bizi bambaşka bir müellife götürmektedir. Bu zat çok ilginç bir şahsiyete ve maceracı bir ruha sahip birçok eser kaleme almış velud bir yazar olan şiirlerinde Kesbî mahlasını kullanan aynı zamanda müstensih olarak da bazı eserlerde kaydı görülen Seyyid Mehmed Haşim Efendi'den başkası değildir.

\section{Meçhul Bir Tarihçi: Kesbî Mehmed Haşim}

Bibliyografik eserlerde ve kataloglarda Mehmed Haşim'in adı, Ferah Ali Paşa'nın kâtibi olarak onun yanında Anapa' da $^{8}$ (1781-1785) bulunduğu sıradaki olayları ve yörenin durumunu Çerkez diyarının ahvalini anlatan Ahvâl-i Anapa ve Çerkes diye sonradan adlandırılan bir eserin müellifi olarak geçer. Ayrıca yine ona ait seyahatname türünde olan, vazifeleri dolayısıyla gezip gördüğü yerlerin acayip olaylarını garib adetlerini kaleme aldığı ve Imâ-i Törehâ-yı Büldenân adını verdiği bir başka eseri daha mevcuttur. Kimliği meçhul müellifin bunların dişında herhangi bir çalışması olup olmadığı konusunda bugüne kadar bir tesbit yapılamamıştır'.

6 İstanbul Üniversitesi Ktb. nr. TY. 5945'te kayıtlı bu eser daha mufassaldır. Tavsifi için bk. İbretnüma-yı Devlet, s. XXXI; Ayrıca bu nüsha üzerine müstakil tanıtımda da farklı eser olduğu yorumu hakimdir: bk. A. Aslantürk-F. Bozkurt, “18. Yüzyılın İkinci Yarısına Dair Önemli Bir Osmanlı Tarihi: İbretnüma-yı Devlet-i Câvid”, Sosyal ve Kültürel Araştırmalar Dergisi, II/3 (2016), s. 155-194. Bununla birlikte bunun Topkap1 Sarayı Müzesi Kütüphanesi'nde bulunan diğer bir eser (Hazine, nr. 1572) gibi Kesbî Mustafa'ya ait olma ihtimali ihtiyatlı dille belirtilmiştir (Serkan Osmanlığlu, Mustafa Kesbî̀nin 1768-1774 Harbi Vekayii, Marmara Üniversitesi Türkiyat Araştırmaları Enstitüsü, İstanbul 2017, s. 22-30). Topkapı Sarayı Müzesi Ktp. Hazine nr.1572 hakkında ise bunun İbretnüma'nın ikinci telifi olduğu fikri mukayeselerle savunulmuş ve eser üzerinde yazdığı gibi Zekeriyazade'ye değil Mustafa Kesbî’ye ait olarak gösterilmiştir (aynı tez, s. 11-22).

7 Öğreten, "Kesbî Mustafa Efendi", s. 306-307.

8 Bugün Rusya Federasyonunda, Krasnador Krayı'nda, Kuban nehri havzasında sahil kenti durumundadır (bk. C. Fedakâr, "Anapa", DİA, Ek I, s. 94-95).

9 Seyahatnamesi vesilesiyle hakkında küçük birkaç etüt yapılmış, müellifin kimliği konusu daha sonraki çalışmaya bırakılmıştı (Bununla ilgili ilk bilgiler için bk. İ. Şahin, "XVIII. Yüzyılın Sonlarına Ait Bir Seyahatname ve Osmanlı Rumelisi", International Congress of Turkish Studies 18th CIEPO Symposium, Berlin 2010, s. 781-787; İ. Şahin-F.M. Emecen, "XVIII. Yüzyılın Sonlarında Bir Osmanlı Seyyahının Kocaeli Yöresi ile İlgili Tesbit ve Gözlemleri”, Uluslararası Karamürsel Alp ve Kocaeli Tarihi Sempozyumu, Bildiriler, II, 2016, s. 511-515). Seyahatname üzerinde değerli meslekdaşım İlhan Şahin ile beraber neredeyse 20 yılı aşan ve fakat çeşitli işlerin araya girmesi sebebiyle bir türlü yayımlama firsatı bulamadığımız metni, sonunda tamamlayıp basılmak üzere Türk Tarih Kurumu'na teslim ettiğimizi belirtmek isterim. 
Mehmed Haşim Efendi hakkında bahseden ilk kaynaklar, Ferah Ali Paşa'nın durumunu anlattığı Ahval-i Anapa ve Çerkes adlı eseri vesilesiyle onun hakkında bazı küçük bilgilere yer vermişlerdir. İlk olarak Ahmed Cevdet Paşa, Tarih'ini yazarken kullandığı kaynaklar arasında bu risaleyi zikredip müellifini Haşim Efendi olarak tanıtmıştır. Eserini de Haşim Efendi Mecmuası adıyla anmış, onun Ferah Ali Paşa'nın kâtibi sıfatıyla Çerkezistan'a gittiğini, hayli müddet orada bulunarak mühim evrakın suretlerini kaydedip "nice mevadd-1 garibeyi” toplayarak bu mecmuayı meydana getirdiğini bildirmiştir ${ }^{10}$. Ayrıca Cevdet Paşa, ilerleyen kısımlarda Ferah Ali Paşa'nın ahvalinden söz ederken eseri Haşim Efendi'ye atıfla kullanmış ve onun kendisiyle ilgili verdiği bazı bilgilere de bu vesileyle temas etmiştir ${ }^{11}$.

Bursalı Mehmed Tahir de benzeri şekilde Ferah Ali Paşa'nın kâtibi olarak onun hizmetinde bulunduğunu, Abaza ve Çerkes kabileleri hakkında mühim bir etnografik ve tarihi eser kaleme aldığını belirtir, ayrıca Tosyalı olduğunu ekler ${ }^{12}$. Tosyalı olduğu bilgisinin kaynağı belli değildir, atıf yapılan mecmuasında ve diğer eserlerinde böyle bir bilgiye rastlanmaz ${ }^{13}$. Bunun dışında Haşim Efendi Mecmuası'nın bugüne kadar bilinmeyen Leiden nüshası vesilesiyle bu nüshayı tanıtıcı geniş bir makale kaleme alan Jan Schmidt hayatı hakkında Cevdet Paşa'nın ve Bursalı Mehmed Tahir'in verdiği bilgilerden hareketle bazı yeni konulara temas eder, onun kitabetten yetişme olarak Tosyalı olmasından da hareket edip hemşehrisi Ebubekir Râtib Efendi'nin çevresine mensubiyetiyle alakalı bazı tahminlerde bulunur ${ }^{14}$.

Anlaşılacağı üzere Mehmed Haşim, daha çok Ferah Ali Paşa ve Anapa bölgesi hakkında yazdığı eserle tanınmış durumdadır, kimliği ve biyografisi hakkında tatminkâr bilgilere ulaşılamamıştır. Bununla beraber zikredilen eserinde kendisiyle alakalı bazı notlara yer verdiği de hemen dikkati çeker. Bu bilgiler kısmen Schmidt tarafından kullanılmıştır. Söz konusu eserin nüshaları muhtemelen farklı telif safhaları geçirdiği için bunların bazılarında kendisinden bahsettiği kısımlar atılmış veya üçüncü şahıs ifadeleriyle belirtilmiştir. Yalnız Cevdet Paşa'nın Şeyhülislam Arif Hikmet Beyefendi'nin meşhur kütüphanesinde gördüğü nüshanın, birinci ağızdan anlatılmış bir özellik taşıdığı Cevdet Paşa'nın Haşim Efendi

10 Tarih-i Cevdet, I, 9.

11 İlgili uzun bahis Tarih-i Cevdet, haz. Abdülkadir Özcan, III, Ankara 2018, s. 177-261.

12 Osmanlı Müellifleri, III, 162-163.

13 Bu bilginin menşei bilinmemektedir. Mehmed Haşim’in ayrıca Edirneli olduğuna dair bir başka kayda da yukarıda temas edilmişti. Bunun dışında o dönem için aynı adı taşıyan bir de Amasyalı Haşim Efendi’nin ismine rastlanır. Bu zatın müellifimizle ilgisi konusu meşkukdur. İlerleyen bahislerde bunlar hakkında bilgiler verilecektir. A. Öğreten ise İbretnüma müellifi olarak tanıttı̆̆ı Mustafa Kesbî’nin (yani aslında Mehmed Haşim'in) Divan'ında Tırnova Pazarlık Cami inşası için düşürdüğü bir tarih vesilesiyle Tırnovalı olabileceğini belirtmişse de (İbretnüma, s. XVI, XXVII) böyle bir tarih düşürmüş olması onun buraya nisbet edilmesini gerektirmez.

14 Jan Schmidt, "Mehmed Hâşim Efendi’s Memorandum (Mecmu'a) on Circassia of 1213 (1798-9): Contents, Style, Textual, History and a Hitherto Unknown Autograph Kept in the Library of Leiden University", Osmanll Araştırmaları, XXVI (2005), 413-479. 
ile alakalı kendisinden bahsettiği yerlere atıf yapmasından açık şekilde anlaşılır ${ }^{15}$. Diğer nüshalarda Cevdet Paşa'nın doğrudan müellif ile ilgili naklettiği anekdotlar bulunmaz. İlginç olan taraf Haşim Efendi'nin kaleme aldığı aşağıda belirtilecek olan diğer eserlerinde de aynı şeklin görüldüğüdür; Haşim Efendi bunları her defasında farklı yazmış, kendisini direkt "kopyalamamış", bazı kısımları bilahıre iptal, bazılarını ise adeta yeniden tanzim etmiştir. Bu sözü edilen eserde Haşim Efendi metin içinde kendisini çok açık şekilde Kesbî mahlasıyla anmıştır. Ayrıca ileride bahsedileceği gibi başka telifatında da bu eserine yaptığı atıflar yer almaktadir.

Ferah Ali Paşa'nın faaliyetleri ve Çerkez diyarının adetleriyle alakalı bu önemli eserin yanı sıra Mehmed Haşim'in yukarıda belirtildiği üzere bir seyahatnamesi mevcuttur. Bu seyahatname, Topkapı Sarayı Müzesi Kütüphanesi'nde (TSMK) Hazine, nr. 1564'te kayıtlı mecmuanın içinde yer almakta, müsveddesi ise Ali Emiri Kütüphanesi'nde bulunmaktadır ${ }^{16}$. TSMK' da bulunan mecmua hem Ahval-i Anapa ve Çerkes hem de seyahatnameyi bir arada ihtiva eder, muhtemelen temize çekilerek ve yeniden tanzim edilerek hazırlanmış bir takdim nüshası özelliği taşır. $\mathrm{Bu}$ ikinci eserinde yani seyahatname nüshasında müellif kendisi hakkında çok değerli bilgiler verir. Bunlar Haşim Efendi'nin kariyeri ve ortaya koyduğu diğer eserlerinin teşhisine yardımcı olabilecek önemdedir.

Bahse mevzu iki nüshada yer alan beyanlardan yola çıkılarak Haşim Efendi’nin hayatı hakkında yeni bilgilere ulaşmak mümkün görünmektedir. Ayrıca ona ait iki eserde kendisini Kesbî mahlasıyla belirtmesi, bu unvanı isminde taşıyan Kesbî Mustafa ile aynı şahıs olduklarına önemli bir başka karine sağlar.

\section{Kesbî Mehmed Haşim ve İbretnüma}

Öncelikle doğrudan adının geçtiği ve kendi telifi olduğuna şüphe bulunmayan seyahatnamesinin hatime kısmı, müellifin teşhisi ve bağlantıları açısından dikkat çekici bilgiler temin eder. Müellif eserin baş tarafında kendisini Haşim Mehmed olarak tanıtır ${ }^{17}$

15 Medine'de bulunan Arif Hikmet Bey kütüphanesinin mevcut kataloğunda bu esere ne yazık ki rastlanamadı. J. Schmidt ise göremediği bu nüsha ile ilgili bir kataloğa işaret eder: "Mehmed Hâşim Efendi’s Memorandum", s. 414. Cevdet Paşa'nın alıntılarından anlaşılan husus bu nüshada müellifin kendisinden doğrudan bahsettiği notların mevcudiyetidir. Arif Hikmet Beyefendi'nin Medine'deki kütüphanesi adeta kapanın elinde kalmış, pek çok eser ya kaybolmuş ya da başka yerlerde zuhur etmiştir. 1950'de 7.662 ciltlik 5.404 eserin mevcut olduğu tesbit edilen kütüphaneden geriye 1984 kayıtlarına göre 4.373 kitap ve 677 mecmua kalmıştır (Mahir Aydın, "Şeyhülislam Arif Hikmet Beyefendi”, Belleten, LIV/209, Ankara 1990, s. 249).

16 Bu nüsha İstanbul Millet Ktp. Ali Emiri, Coğrafya, nr. 3’te kayıtlı bulunup tam bir müsvedde olmaktan çok düzgün yazılmış ama kenarlarda ek çıkmaların bulunduğu bir şekildedir. Derkenar notları metinle alakalı olup TSMK'daki nüshada bunların çoğu metne yedirilmiştir. Bu metin ile TSMK' daki metin arasında açık benzerlik vardır ama müellif TSMK nüshasını adeta ikinci bir telif aşamasından geçirmiş gözükmektedir.

17 “.. hikmet-i ilâhiye ile tayerân ve rü’yet-i müşâhede-i seyrân olunan emkine-i büldân tuhfe-i nekerât-l -1213midâd olmak üzere tahrîr ve iber-i nazar-endâzân içün eğerçi yâdigâr-l yârân kılınup afv ve inâyât-ı kadrdân-ı fütüvvet-dârândan mütemettî ve istid 'â-yı fakîrânem oldur ki vâki 'olan taksîrât-ı dervişânem afv ve safh ile her bilâdın ahvâl ve etvâr ve töre ve âyînleri âşinâlığı ile iktisâb-ı tenşît-i fu' âd olunacağ müstağnî- $i$ 
ve içeride geçen bir şiirinde de Kesbî mahlasını kullandıktan sonra hatime kısmında şu malumata yer verir:

“Bin yüz seksen üç senesi gurre-i Muharremü'l-harâmında [7 Mayls 1769] Ordu-yı hümâyûn İsakçı sahrâsına dâhil oldukda mektûbî-i defterî hulefâlarından umûr-ı mühimme Devlet-i aliyye Hotin cânibine bir kâtib irsâli mühimm ve muktezî olmağla bu fakīr-i b̂̀çâreyi irsâl ve ba 'de'l-vusûl yirmi yedi gün ve gece mahsûr olup ahvâl-i âcizânem perîşân olmağla ba 'de'l-halâs devâ içün Deraliyye'ye avdet ve rikâb-ı müstetâb-ı husrevâneye ref' ve takdîm olunan hulâsa ve takrîrât tahrîri hizmetine muvâzabet ve medâr-ı ma 'âşıma ve bir işime yaramadiğından ba 'de zamân terk olunup ber-vech-i mübeyyen seyrân olundu"'18.

Bu bilgi bize Haşim Efendi'nin Defterdar kaleminde kâtib olarak istihdam edildiğini sarahaten gösterir. Ayrıca 1768 seferi için cepheye görevle gittiğini, Ruslar'ın Hotin kuşatması sırasında bazı işleri görmek üzere vazifelendirildiğini ortaya koyar. Buradan hareketle Ahmed Cavid Bey'in Müntehabat adlı eserine bakıldığında, aynı şekilde Hotin'e memur edilen defterdar kâtiplerinden Mehmed Haşim'in adına rastlanır. Ahmed Cavid Bey, bu münasebetle bizzat Mehmed Haşim tarafından kaleme alınan sefer ahvaliyle ilgili uzun bir Takrir'e eserinde yer verir. Bu Takrir'in başlığında ise: "Şıkk-1 evvel mektubcusu hulefâsından Şemsî Emirzâde es-Seyyid Mehmed Hâşim Efendi'nin Takrîridir. Sene 1183” ifadesi yer alır ${ }^{19}$. Bu durumda çok açık olarak Mehmed Haşim'in Şemsî Emir Efendi'nin oğlu olduğ $\mathrm{u}^{20}$ ve defterdar dairesinde mektubcu kaleminde görev yaptığı anlaşılır.

Mehmed Haşim'e ait olan Takrir, aslında 1768 seferi başlangıcı ve Hotin kuşatma ahvali ile bu yörede meydana gelen olaylara dairdir ve bu kısmın ayrıca müellif adı belirtilmeksizin başka müstakil nüshaları da mevcuttur. Aynı bahisleri Kesbî Mustafa’ya atfedilen İbretnümayı Devlet adlı eserin içinde de bulmak mümkündür ${ }^{21}$. Hem bu Takrir'de hem de İbretnüma-

takrîr ü beyândır. Ancak tesmiye-i ism-i kitâb te'emmül olundukda "Îmâ-yı Törehât-ı Büldânân" -1213-târîh-i tesvîdi olup tesmiye olunduğu hâlde ta 'bîrâtda vâki "olan taksîr-i âcizânem dâmen-i afv ile mestûr buyurulmak mukarrer ise dahi dedi Hâşim Mehmed "Güftem be-nekerât" -1213- zîrde tahrîr u beyân [2a] olunduğu üzere.." (Seyahatname, TSMK, Hazine, nr. 1564, 1b).

18 Seyahatname, TSMK, Hazine, nr. 1564, 142b. Aynı bilgi müsveddede de yan notta yer alır.

19 Ahmed Cavid Bey, Müntehabât, haz. Adnan Baycar, İstanbul 2004, s. 283.

20 J. Schmidt'in tanıttı̆̆ Ahval'in Leiden nüshasında da hatimede müellifin kendisini Emirzâde Seyyid Mehmed olarak tanımladığını belirtilir ("Mehmed Hâşim Efendi’s Memorandum”, s. 415). Diğer nüshalarda bu kayıt yoktur. Ayvansarayî, 1120'de vefat eden Emir Paşa/Seyyid Mustafa Paşa oğlu Seyyid Mehmed Haşim’den bahsedip bunun tezkire-i evvel olduğunu, birçok mansıba atandığını ve 1177/1763'te vefat ettiğini yazar (Vefeyât-l Selâtin ve Meşâhir-i Ricâl, haz. F. Ç. Derin, İstanbul 1978, s. 23). Başmuhasebecilik ve Cizye muhasebeciliği de yaptığı anlaşılan (1168 Şevval/Temmuz Ağustos 1755) bu zatı (Vak'anüvis Hakim Efendi Tarihi, haz. Tahir Güngör, Marmara Üniversitesi Sosyal Bilimler Enstitüsü, İstanbul 2014, s. 263) Müstakimzâde ünlü hattatlar arasında da zikreder ve Emir Paşa oğlu Seyyid Mehmed Haşim olarak anıp pederi yanında Sivas Tekkesi dahilinde medfun olduğunu bildirir (Tuhfe-i Hattâtîn, nşr. İbnülemin Mahmud Kemal, İstanbul 1928, s. 487; Sicill-i Osmanî' de görevleri ile ilgili daha geniş bilgi vardır: IV, 623). Baba adı dahi benzerlik arz etmiş olsa da bu zatın başka biri olduğu anlaşılıyor. Bununla beraber Mehmed Haşim’in bu aileyle irtibatlı olma ve bir başka ferdi bulunma ihtimalini bütünüyle göz ardı etmemek gerekir.

21 İbretnüma, s. 115'ten itibaren başlayan: "Muhasara-i evvel-i serhadd-i Hotin” kısmı. Burada Haşim Efendi takririnde kullandığı birinci şahıs ifadelerini yer yer çıkarıp metni ikinci defa telif etmiş görünür. 
yı Devlet'te müellif kendisi hakkında benzeri bilgiler vermektedir. Aşağıda tekrar temas edilecek olan bu malumat, çok sarih şekilde İbretnüma-yı Devlet adlı eserin yazarının veya derleyeninin hem Takrir hem de doğrudan müellifin adıyla tanımlanabilen diğer üç eserin (Ahval-i Anapa ve Çerkes, Seyahatname ve Divan) sahibi ile aynı şahıs olduğuna şüphe bırakmaz. Nitekim müellifin Hotin tarafina görevlendirilen Elhac Selim Ağa'ya terfik edilecek bir kâtib arandığında kendisinin uygun görülüp onun yanında Hotin'e gittiğine dair ifadeleri, bu hususu destekleyen açık bir delil olarak gösterilebilir.

İbretnüma'da bu durum şöyle belirtilir: "Elhac Selim Ăga'ya sâhib-i devlet Yağllkcızâde Emin Paşa'nın infi'âli olmağla katl ü idâmına bedel üç yüz kise nükūd i'tâ ve kal'a-i mezkûrun binâsını inşâ ve askeriyenin ta 'yînâtını vermek üzere defterdarlık hil 'atini ilbâs ve müsâra 'aten isrâsı fermân buyruldu. Ve keyfiyyet-i kal'a ve ahvâl-i mikdâr-l asker ve zehâir ve etvâr-l vüzerâya dikkat ve tahrîr ve seyr-i serî' ile ifâde içün bu fakīr-i pür-taksîri dahi cânib-i defterîden ta "kīb eylediler"'22.

Aynı ifadeler daha ayrıntılı olarak Takrir'de yer alır ve "ahz ve istishâb-1 kâtib" özel başlığı altında belirtilir. Burada Elhac Selim Ağa'nın İsakçı'ya dört saat mesafedeki müellifin de bulunduğu menzile geldiğinde kendi çadırları yakınına konduğu söylenerek şöyle denir: “...müdâvemet eylediğim şıkk-ı evvel mektubcusu kalemin çadırı kurulduğu mahalle gelüp efendilerimiz hazretlerinin bu âciz-i nâcizlerine olan iltifat-ı aliyyeleri merkūmun meşhûdu oldukda der-akab defterdar-ı vakt Meş'aleci İbrahim Efendi'ye varıp bâ-arzuhâl inhâ ve kalem kâtiblerinden Mehmed Haşim'i ma 'iyyetime terfik eylemedikçe umûr-ı me'mûreme azîmet muhâldir... deyü istid'â eyledikde... nâçâr İsakçı sahrasına nüzûlümüzün günü ki bin yüz seksen üç senesi Muharremü'l-haramının üçüncü günüdür, ... vedâ edip Hotin canibine azîmet olundu.."23.

Mehmed Haşim ile İbretnüma arasındaki bă̆ sadece bu benzer ifadelerle sınırlı değildir. Ayrıca Mehmed Haşim İbretnüma' da muhtelif bahislerde yeri geldikçe hem seyahatnamesine hem de Ferah Ali Paşa'yla ilgili risalesine atıflarda bulunmuştur. Bunlardan bir sonraki bahiste söz edilecektir. Bütün bu kısımda ortaya çıkan ana tesbit, çok açık şekilde İbretnümayı Devlet adlı eserin yazarının/derleyeninin Kesbî mahlaslı Mehmed Haşim Efendi olduğudur. Meseleyi böylece sarahate kavuşturduktan sonra biyografisine dair çok az bilgiye ulaşılabilen bu "meçhul müellifin" hayatıyla ilgili yeni ayrıntılara geçebiliriz.

22 İbretnüma, s. 116.

23 Ahmed Cavid, Müntehabat, s. 288-289. Keza İbretnüma nüshasının bir başka yerinde sunulan bir arzın Mehmed Haşim tarafından yazıldığına dair atıf vardır. Arz defterdara ait olup sonuna şu not düşülmüştür: "Kâtibimiz Mehmed Hâşim mevâcib ihrâcında yedi sekiz defa ben yazdım deyü haber verir" (İbretnüma, s. 182). 


\section{Mehmed Haşim Efendi’nin Hayatı ve Eserlerine Dair Notlar}

Yukarıda da belirtildiği üzere Seyyid unvanlı Şemsî Emir Efendi’nin oğlu olan Mehmed Haşim'in kitabetten yetişme olduğuna şüphe bulunmaz. Babasının açık kimliği konusunda şimdilik herhangi bir bilgiye tesadüf edilememiştir. Ancak onun da tedris veya kitabetle alakalı bir meslek mensubu olması muhtemeldir ${ }^{24}$. Mehmed Haşim'in kariyeri hakkında bilgiler eserlerinde kendisiyle ilgili kaydettiği türlü anekdotlardan çıkarılabilmektedir. İleride de temas edileceği üzere ona ait olduğu istidlal edilen devlet teşkilatına dair bir risaledeki bilgilerden hareketle, Hekimoğlu Ali Paşa'nın Kütahya'dan sonra gittiği Sivas valiliği sırasında onun yanında bulunduğu ve kariyerine de muhtemelen bu sırada başladığı söylenebilir ${ }^{25}$. Hekimoğlu Ali Paşa'nın valiliği 1157-1158 (1745-1746) yılına denk düşer ve bu durum Mehmed Haşim'in gençlik yıllarında Hekimoğlu Ali Paşa'nın dairesinde yetiştiğini düşündürür ${ }^{26}$. Nitekim Mehmed Haşim seyahatnamesinde de yeri geldikçe Hekimoğlu Ali Paşa'ya atıflar yapmıştır. Sonradan bir şekilde İstanbul'da kitabet zümresine dahil olduğu anlaşılmaktadır. Buraya hangi "vasıtaları” ve ilişki ağlarını kullanarak girdiği konusunda bilgi yoksa da bu anlamda Hekimoğlu Ali Paşa'nın rolünü göz önüne almak yanlış olmaz. Bundan sonraki ilk görevleri konusunda hiçbir "sır” vermeyen müellif, İbretnüma' da belirttiğine nazaran Enderun hizmetlileri arasında yer almış, 1175 Şevval'inde (Mayıs 1762) dağıtılan akçalardan kendisine muhtemelen Enderun halkına tevzi etmek üzere "mevkuftan" 50.000 guruş tahsisat yapılmıştır²7. Ayrıca 1768 seferine çıkılmadan önce de defterdarlıkça evvelki seferlerin masraflarını, hazine durumunu gösteren listeler çıkarmakla görevlendirilmiş, bunları hazırlayarak üstlerine sunmuştur ${ }^{28}$. Bu bilgiler onun uzunca bir süre maliye kaleminde görev yapmış olma ihtimalini kuvvetlendirir. Muhtemelen dönemin diğer bazı bürokratları gibi paşa kapılarında yetişerek merkezi bürokrasiye dahil olmuştur.

Seyahatnamesinin hatime kısmından istihraç ettiğimiz kendine ait notta, Muharrem 1183 'te (7 Mayıs 1769) İsakçı sahrasına ulaşan orduda "Mektubi-i Defterî halîfelerinden" olduğunu, o sırada savaşların cereyan ettiği Hotin tarafına mühimmat vs. tedariki için

24 Bununla ilgili tahminler için ayrıca bk. yukarıda 20. dipnot.

25 Bu risale müellifi meçhul olarak değerlendirilerek Cengiz Orhonlu tarafından yayımlanmıştır: "Osmanlı Teşkilatına Aid Küçük Bir Risâle: Risâle-i Terceme”, TTK Belgeler, IV/7-8 (Ankara 1967), s. 39-47.

26 “.. kırk-elli sene mukaddem veliyyü’n-ni 'am merhûm Hekimzâde Ali Paşa efendimiz hazretleriyle Sivas şehrinde ikāmet ettiğimiz hengâmda..”, "Osmanlı Teşkilatına Aid Küçük Bir Risâle: Risâle-i Terceme”, s. 41. Bu önemli ipucunun Mehmed Haşim'i işaret ettiğine ileride temas edilecektir. Metinde Ali Paşa'nın hangi tarihte Sivas’ta bulunduğu belirtilmemekle birlikte, C. Orhonlu bunu Hekimoğlu Ali Paşa'nın İran cephesindeyken Sivas eyaletine ismen tayin olunduğu 1728 Ağustos'u olarak verir (“Osmanlı Teşkilatına Aid Risale”, s. 39). Halbuki Ali Paşa Sivas'a gelmeden başka bir eyalete tayin edilmiştir. Sivas’a tayin tarihi ise Kasım 1745'tir. Görev yerine Kütahya'dan hareketle 1746'da gelmiştir (İzzi Süleyman Efendi, İzzî Tarihi, haz. Z. Yılmazer, İstanbul 2019, s. 202, 241-244. Ayrıca bazıları arşiv kayıtlarından çıkan bu bilgiler için Hekimoğlu Ali Paşa üzerine doktora tezi hazırlayan Mehmet Yılmaz Akbulut'a teşekkür ederim).

27 İbretnüma, s.181.

28 Bu listeler hazine gelirleri sefer masrafları, türlü harcamalara ait olup İbretnüma' da yer alır (s. 182-291). 
kâtib olarak görevlendirildiğini, 27 gün ve gece burada mahsur kaldığını, çok zorluklar çektiğini, sonra İstanbul'a döndüğünü belirtmiştir. İstanbul'a döndükten sonra kitabet işini sürdürdügünü fakat yeterli maaş alamadığı için ayrılıp bundan sonra eserinde konu edindiği yerlerde dolaştığını ifade etmiştir ${ }^{29}$. Ahmed Cavid'in Müntehabat'ta yer verdiği Takrir'de ise söz konusu görevi ve başından geçenler ile ilgili ayrıntılar daha fazladır. Bunları bir nevi hatırat notları şeklinde kaleme almıştır.

Buna göre defterdar dairesinde mektubcu kalemi halifesi ${ }^{30}$ olarak çalışırken orduyla birlikte hareket eden Mehmed Haşim, Hotin'in zor durumda olduğu haberi üzerine buraya gereken desteği sağlamak ve zahire temin etmekle görevlendirilen Hacı Selim Ağa tarafından kâtib olarak seçilir. Haşim Efendi, o sırada mektubçu kesedarı Kara Hafız Mustafa Efendi’nin himayesi altında çalışmaktadır. Böyle sonu belli olmayan bir görev için seçilince bu duruma itiraz eder, Selim Ağa ile gitmeyeceğini defterdara bildirir. Fakat isteği kabul görmez ve gelen bir tezkire ile Hotin'e sevk edilen heyete katılmak mecburiyetinde kalır. Bu durumu, "ben cerî, cesur ve hall u akde muktedir değilim diye ne kadar feryâd eyledim ise çâre olmadı" diye açıklar' ${ }^{31}$.

Selim Ağa ile birlikte İsakçı'dan hareket edip (3 Muharrem/9 Mayıs) Boğdan sınırından geçer ve Hotin kalesine ulaşır. Ona göre Hotin kalesi istihkâm olarak iyi bir durumda değildir; burada gerekli mühimmatın teminine çalışır, gelen askerlerin zahire ihtiyaçları için çabalar. Bu sırada Hotin civarında bulunan Ruslar kaleyi yeniden muhasara altına alırlar. Mehmed Haşim gün be gün bu 27 gün süren kuşatmayı anlatır, olup bitenleri, ordunun durumunu, paşaların ve askerlerin vaziyetini çoğu defa tenkidi bir dille nakleder. Seyahatnamesinin hatimesinde belirttiği "yirmi yedi gün ve gece mahsûr olup ahvâl-i âcizânem perîşân olmağla" ifadesi de bu duruma yapılan bir atıftır. Ayrıntılı Takrir'inde bunu, “yirmi yedi gün giriftar olduğumuz cülleden rehâ bulup..." şeklinde ayrıca ifade eder ${ }^{32}$. Yine burada belirttiğine göre Hotin'den ayrıldığında ağır şekilde hastadır, vücudu şişmiş, eğilip kalkmaya ve hareket etmeye mecali kalmamıştır. Ata binemediği için arabayla Edirne’ye kadar getirilmiş, bu sırada yolda yavaş yavaş iyileşmeye başlamıştır.

29 Seyahatname, TSMK, Hazine, nr. 1564, 142b.

30 Mektubcu Efendi odası bilindiği kadarıyla sadaret kethüdasına bağlı çalışan bir kalemdi (Muzaffer Doğan, Osmanlı Devletinde İçişlerinin Yönetimi: Sadaret Kethudalı̆̆l, 1730-1836, Ankara 2016, s. 21, 24). Defterdarlığın da mektubcu odası olduğu bilinmektedir. Mektubcu kaleminin personelini teşkil eden katiplerin halife olarak nitelendirildiğini belirtmek gerekir. Mektubi-i Defterî kalemi, başdefterdarın mühim işlere ve havale olunan kağıtlara önemine göre yazacakları takrir ve telhisleri hazırlıyordu. Yani mühim evrakın kaydı burada tutuluyordu. Keza bazı mukataanın icab eden beratları da burada tanzim olunurdu (İ. H. Uzunçarşıll, Osmanlı Devleti 'nin Merkez ve Bahriye Teşkilatı, Ankara 1984, s. 352). Bu görev tanımları Mehmed Haşim'in icra ettiği vazifelerle aynen uyuşmaktadır.

31 Ahmed Cavid, Müntehabât, s. 288.

32 Ahmed Cavid, Müntehabat, s. 307-308. 
Mehmed Haşim Edirne'de iken sadrazamlıktan azledilen Yağlıkçızade Mehmed Emin Paşa'nın mallarının müsadere edilip idam olunduğu bilgisini verir. Paşanın idamı (11 Eylül 1769) üzerine İstanbul'a gider, kitabetini eskisi gibi kalemde sürdürmesi ile ilgili tezkire alır. Ancak bu hizmeti maaş karşılığı değil hasbî kitabet şeklindedir ${ }^{33}$. Bu arada kendisinin tekrar cephedeki orduya çağrıldığı halde gelip kitabet hizmetine başlamadığı yolunda âmiri durumunda olduğu anlaşılan Mektubcu vekili Darendeli Mehmed Emin Efendi’ye tezkire ulaşır, "kalemden redd ü teb 'id olunması" istenir. Kendi beyanına göre, Darendeli Mehmed Emin Efendi bu talimatı bizzat ona tevdi eder ve artık "kalem odasına girmemesini" bildirir; ama diğer görevliler yanında küçük düşürmemek için kalemde "umûr-1 mühimme tahrîrine muktedir" kâtib olmadığından orduda bulunan büro âmirlerinin kalem odasına girilmesini yasakladıklarını, ancak kendi odasında bulunmasından men etmediklerini söyleyip onu teselli eder. Böylece Mehmed Haşim, ordunun İstanbul'a dönüşüne kadar kalem odasındaki vazifesini sürdürür ${ }^{34}$.

Mehmed Haşim'in bu uzun Takrir' inde kendisi hakkındaki son kayıt budur. İbretnüma'ya da takririnin kısaltılmış versiyonunu derç ederken kendisiyle ilgili anekdotların bazılarını çıkarmıştır ${ }^{35}$. İbretnüma' da bundan önceki birtakım görevlerine dair kendisinden bahsettiği kısımlarda bilgi verdiği de dikkati çeker. 1768 seferi için mensup olduğu Defterdarlık kalemiyle sefere gitmeden önce, 1179 (1765-1766) yılında memuriyetle, daha sonra Ferah Ali Paşa'nın kâtibi olarak tekrar gideceği Çerkes bölgesine yollandığını, burada çıkan madeni teftiş ettiğini, bir numune alıp döndüğünü bildirir ${ }^{36}$. 1768 seferi başladığında da Hotin'e gitmeden önce İsakçı kalesinin tamir ve mühimmatının tedarikiyle görevlendirilmiştir ${ }^{37}$. Ordu

33 Burada Mehmed Haşim'in görev verildikçe yaptı̆̆ iş karşılı olmadığı açık şekilde ortaya çıkar.

34 Ahmed Cavid, Müntehabat, s. 310-311; “....merkūm Seyyid Hâşim dahi Deraliyye’ye i âde ve ba 'de'l-vusûl ber-üslûb-ı sâbık Rikâb-ı hümâyûnda bâki kalan kalem-i merkūma müdâvemet ve rûz u şeb umûr-ı mühimme ve sâir hasbî kitâbete muvâzebet eder iken Ordu-yı hümâyûnda kalemimiz re'isinden mektubcu vekili Darendeli Nâmı Mehmed Emin Efendi'ye bir kit'a mektûb vürûd edip hülâsa-i mefhûmunda Ordu-yı hümâyûndan Deraliyye'ye gidüp şimdiye kadar gelmeyen Kâtib Mehmed Hâşim'in Ordu-yı hümâyûna gelip hizmetde bulunmalar teklif oluna. İtâ 'at ve kabûl etmedikleri sûretde şimdilik kalemden redd ve teb 'îd oluna deyü te'kîden ve tafsîlen tahrîr olunmuş. Efendi-i mûmâ-ileyh çâkerlerin ihzâr ve mektûb-ı merkūmu kurâ'et ve tefhim ve fimâ-ba 'd kalem odasina girmeyesiz deyü tenbîh ü te'kîd eyledi. Kalem-i merkūmda umûr-ı mühimme tahrîrine muktedir kâtib olmadığından zarûrî Ordu-yı hümâyûnda olan efendilerimiz kalem odasina ruhsatdan men 'eylemiş, ancak benim odamdan men ' etmemişdir deyü akrân u emsâlimiz meyâninda tevkìr ve tefavvuk ve hürmet edüp ordu gelinceye değin mektûbî efendilere mahsûs olan odaya âmed ü reft olunur idì".

35 İbretnüma, s. 115-133. Bu bahsin sonunda kendi adını andığı şu ibare ile tarih düşürdüğü görülür: "Filizzât-1 kalem-i Kesbî-i nâdide-bûyâdandır ki/1213".

36 İbretnüma, s. 65.

37 Anadolu beylerbeyisi iken sadrızam olan Hamza Paşa'nın bu makama getirilmesi (7 Ağustos 1768) dolayısıyla sadrıazam olmadan önce Kütahya valisi iken dönemin defterdarı Sârım İbrahim Efendi'nin ona karşı küçümseyici hitabla mektub gönderdiği, ulağın yola çıktığı gün sadarete getirildiği haberi geldiği, defterdarın büyük telaşa düş̧üğü şeklinde bizzat şahit olduğu hadiseyi naklederken kendisinin mülazim sıfatıyla Bâb-1 Defterî mektubcu kaleminde evrak-1 mühimmenin tahririne memur olduğunu ifade eder: "Bu fakīr-i pür-taksîr ol vakit Mektûbî-i defterî kaleminde mühimme tahrîrine me'mûr buyrulduğum ecilden mülâzemet ve kalem-i mezkûra müdâvemet eder iken müşârün-ileyh Sârım Paşa defterdar-l vakt bulunup...", İbretnüma, s. 74. 
Edirne'de toplandığında kendisi İsakçı'da bulunuyordu ${ }^{38}$. Ardından da yukarıda Takrir'inde sözünü ettiği Hotin'e gitmişti. Bu arada yine cephelerde çeşitli işlerle görevlendirilmiş olduğu düşünülebilir.

$\mathrm{Bu}$ memuriyetleri sırasında önemli isimlerle tanışıp bir kısmı sonraları daha büyük rütbelere hatta vezaret makamına erişecek olan bürokratlardan, çelebi efendilerden ve dönemin münevverlerinden oluşan bir çevre edindiği düşünülebilir. Kendisi gibi kitabetten gelme olup Şumnu kesiminde görevler icra eden Ferah Ali Paşa, Ahmed Cavid Bey, Reisülküttab Ebubekir Râtib Efendi, Defterdar Sârım İbrahim Efendi/Paşa, Süleyman Feyzi Efendi/Paşa, Koca Abdi Paşa ve tabii yanında yetiştiği anlaşılan Hekimoğlu Ali Paşa bunlar arasında sayılabilir. III. Selim döneminde Tersane emini iken katledilecek olan Hacı Selim Ağa ile birlikte çalışmış olması da ayrıca dikkate değerdir ${ }^{39}$. Takrir'de yer alan bilgiler onun Sadrazam Yağlıkcızade ekibine mensubiyetini hatıra getirir. Bir süre nekbete uğramasının sebebi de muhtemelen bu yüzdendir.

Bundan sonraki görevlerini ancak yine eserindeki ifadelerinden çıkarmak mümkündür. Muhtemelen bir süre İstanbul'da hasbi olarak maaşsız hizmet etmiş olmalıdır. İcra edilen seferlere katılmış olması da pekâlâ mümkündür. Onun en azından Küçük Kaynarca Anlaşmasından (1774) sonra Kırım konusuyla ilgili görüşmeler yapmak için İstanbul'a gelen Rus elçisi Repnin'in faaliyetleriyle ilgili gizli bir görev icra ettiği bilinmektedir. Kendi beyanına göre İstanbul'daki elçilerin Büyükdere'de ziyafet bahanesiyle bir araya gelmeleri sırasında buradaki konuşmaları, bizzat kendisine gelen çok dil bildiğini belirttiği İstavri adlı bir Rum aşçıdan öğrenip rapor halinde sunmuştur. Íbretnüma adlı eserinde bu rapora yer verdiği, burada elçilerin İstanbul'u nasıl ele geçirebileceklerinin planlarını yaptıklarını anlattığı görülür ${ }^{40}$. Bu istihbarat vazifesi dolayısıyla onun kitabette gizli görevler üstlenmiş olma ihtimali ortaya çıkarsa da bu hususta başka bir bilgiye rastlanmaz. Aslında diğer eserlerindeki bilgilerin de istihbaratçı tabiatıyla uyuştuğunu söylemek yanlış olmaz. Hatta Hotin'e kâtib olarak tayin edildiğinde "etvâr-l vüzeraya dikkat ve tahrîr ve seyr-i serî̀ ile ifade" gibi bir vazifesi olduğunu belirtmiş olması bu manada dikkat çekicidir ${ }^{41}$.

Mehmed Haşim'in seyahatnamesindeki bilgiler onun 1778-1779'da İstanbul'da bulunduğuna işaret eder. Öncelikle cephelerden tanıştıkları anlaşılan Canikli Ali Paşa'nın meşhur risalesinin istinsahını 1 Receb 1192/26 Temmuz 1778'de tamamlamış olduğu görülmektedir. Burada kendisini Seyyid Mehmed Haşim, unvanını ise önceden olduğu gibi

38 İbretnüma, s. XX.

39 Müntehabat, s. 293 vd. Hacı Selim Ağa, Sadrazam Halil Hamid Paşa’nın katlinde rol oynayanlar arasında olduğu için III. Selim tahta çıkınca onu ve oğlu Nazif Efendi'yi katlettirmişti (K. Beydilli, "Selim III", DİA, XXXVI, 420).

40 İbretnüma, s. 432-435. Bunun üzerine yazdığı mütalaa hayli ilginçtir: s. 435-36.

41 İbretnümâ, s. 116. İbretnüma'da müellifin kendisiyle ilgili verdiği bilgiler eserin nâşiri tarafindan da detaylı olarak Mustafa Kesbî’ye nisbetle tesbit edilmiştir: bk. s. XVII-XXVII. 
Defterdar dairesi mektubçu odası halifesi şeklinde vermeyi tercih etmiştir ${ }^{42}$. Ayrıca Kocaderesi âyânı Çelebi Efendi'den bahsederken ve zarif bir zat olan Çelebi Efendi'nin zaman zaman ziyafet ve ahbaplık için İstanbul' dan bazı dostlarını çağırdığını, kendisinin de böyle bir davette bulunduğunu, ayrılırken çok hoşuna giden kiraz ve vişne satın almak istediğini derkenar notu olarak yazarken yine aynı tarihi zikretmiştir ${ }^{43}$. Daha sonra muhtemelen Eflak voyvodasının ikinci kâtibi sıfatıyla onun yanında görev yapmıştır. Eflak voyvodasını, teşrifatını ve bu memleketin adetlerini anlattığ 1 kısımda ikinci kâtipten nakillerde bulunduğunu yazarken açık şekilde kendini ele vermez; fakat anlatımından yakalanan ipuçları bu kâtibin aslında kendisi olduğunu düşündürür ${ }^{44}$. Eğer böyle ise bu durumda onun 1195 ve 1196 yıllarında (1782-83) Eflak'da bulunduğu söylenebiliri ${ }^{45}$. Sonra bir şekilde yine İstanbul'a dönmüş olmalıdır. Eflak ile alakalı yazdıkları bir görgü şahidinin kaleminden olmak itibarıyla son derece önemli tafsilat ihtiva eder.

Mehmet Haşim'in 1783 'te, 1774 Küçük Kaynarca Antlaşması'nın ardından Kafkasya ile daha yakın ilgilenmek ihtiyacını duyan Osmanlı merkezî idaresinin bölgeye muhafız olarak gönderdiği Ferah Ali Paşa'nın kâtipliğine getirildiği anlaşılmaktadı4 ${ }^{46}$. Bunda özellikle onun daha önce de bu yörede bulunmasının ve bölgeyi tanımış olmasının rolü olduğu kesindir. Ayrıca bu göreve tayininde Ferah Ali Paşa ile olan tanışıklığından çok onun faaliyetlerini ve bölgenin ahvalini merkeze rapor etmek gibi gizli bir görev yüklenmiş olma ihtimali de vardır.

Ahval-i Anapa adlı eserinin girişinde görevlendirilme konusu şöyle anlatılır: "Yeni dünya mesâbesinde olan cibâl-i Abaza'nın fâtihi ve serhadd-i Anapa nâm kal 'anın bânisi Şeyhü'lvüzerâ, cennet-mekân, firdevs-âşiyân merhûm ve mağfiret-nişân Ferah Ali Paşa hazretlerinin hizmet-i ma 'iyyet-i aliyyelerinde mevcûd bulunup müşârün-ileyhin rey ü tedbîrine vukūfu olan kâtibinin alâ-vechi'l-ihtisâr tahrîr ve takrîridir"47. Fakat Mehmed Haşim İbretnüma adlı eserinde bu görevlendirme ile ilgili başka bir ilginç nota yer verir. Buradan Ali Paşa'nın yanına sonradan gitmiş olduğu ortaya çıkar. İbretnüma'daki bilgiye nazaran 1197 (1783)

42 Risalenin TSMK, H. nr. 387'de kayıtlı nüshasında 29b'de müstensih olarak kendisini "Esseyyid Mehmed Haşim, an-hülefâ-yı mektûbî-i defterî" diye tanıtmaya devam eder. Risale için bk. Y. Özkaya, "Canikli Ali Paşa'nın Risâlesi: Tedâbirü'l-Gazavât”, Tarih Araştırmaları Dergisi, VII/12-13 (1969), s. 120-191.

43 Bu kısım müsveddede (Ali Emiri, Coğrafya, nr. 3), s. 136.

44 Seyahatname, 128b-129a.

45 Bu tarihlerde Eflak voyvodalığına Karaca Nikolaki Bey atanmıştı (1782). Hâşim’in İstanbul'da geçinme problemleri yüzünden böyle bir görevi kabul etmiş olduğu konusunda dolaylı bir ifadesi olduğu da dikkati çeker: “...hikmet-i hüdâ fezâdârım olan zügürtlük girîbânımdan tutup berbâd u rüsvâ etmek kasdında olduğu yakīnim olduğundan medâr-ı ta 'ayyüş-i dünyâ olur mülâhazası ve tabî'at-ı rüzgâr ile Eflak voyvodasına ikinci dîvân kitâbetini zarûrî irtikâb ve bin yüz doksan beş senesi Eflak voyvodası ile azîmet..." (TSMK, Hazine, nr.1564, 132a)

46 Ferah Ali Paşa ve faaliyetleri için bk. Zübeyde Güneş Yağc1, Ferah Ali Paşa'nın Soğucak Muhafizlığı (1781-1785), Ondokuz May1s Üniversitesi, Doktora Tezi, Samsun 1998; Cengiz Fedakar, Kafkasya'da Imparatorluklar Savaşı: Kırım'a Giden Yolda Anapa Kalesi (1781-1801), İstanbul 2014, s. 17-89.

47 TSMK, Hazine, nr. 1564, $1 \mathrm{~b}$. 
yılında memuriyetle Çerkes bölgesine deniz yoluyla hareket eden Mehmed Haşim ${ }^{48}$, muhalif rüzgarlar sebebiyle bindiği geminin Kırım'da Yalta ve Balıklava sahillerine sığındığını belirtir. Bu bilgiye beraberindeki Arnavut askerlerinin Rus ordusuna katılması sebebiyle Sadrazam Yağlıkçızade tarafından idam edilen Kahraman Paşa hadisesi dolayısıyla yer vermektedir ${ }^{49}$. Bu durumda onun Ali Paşa ile değil daha sonra bu göreve gittiği ortaya çıkar. Belki de yukarıda sözünü ettiğimiz üzere Ali Paşa'nın faaliyetleri ve bölgedeki vaziyetle ilgili istihbaratta bulunmak amacıyla bu vazife kendisine tevdi edilmiştir. Hazırladığı eserinin bir ölçüde istihbarat raporu olduğunu kabul etmek de mümkündür.

Mehmed Haşim Anapa'daki görevi esnasında özellikle Ferah Ali Paşa’nın Kafkasya'daki faaliyetleri ve icraatı ile başta Nogaylar olmak üzere oradaki kabilelerin durumunu ve yerleşimini de içine alan kıymetli tesbitlerde bulunmuştur ${ }^{50}$. Ahvâl-i Anapa ve Çerkes adıyla bilinen ve yazma halinde bulunan eser, o dönem için Cevdet Paşa'nın da yegâne kaynakları arasında yer almakta, Cavid Ahmed Bey'in yönlendirmesiyle hazırlanmış bulunmaktadır. Ahmed Cavid'in Mehmed Haşim ile yakınlığı olduğuna şüphe bulunmamaktadır. 1218 (1803) yılında vefat eden Ahmed Cavid'in de sarayda Enderun'da yetiştiği ve belki de bu sıralarda Mehmed Haşim ile tanışıklığı olduğu ileri sürülebilir. Mehmed Haşim'in Ahval-i Anapa adlı eserinin sonundaki bir notta “... şeyh-i müşârün-ileyhin tedbîr ve idâresi hâcegân-ı divan-ı hümayundan hâlâ şehremini Cavid Ahmed Beyefendi hazretlerinin tahrirâtından ma 'lûm-ı ilm-i kerîmâneleri olup Kesbî-i pür-taksîrden lede's-suâl ber-vech-i meşrûh takrir etmekle ta 'rifi üzere zabt u tahrîr olundu..." yazılması bu ilişki açısından önemlidir. Bu nüshanın telif tarihi 17 Cemaziyelevvel 1213 (27 Ekim 1798) olarak verilmiştir ${ }^{51}$. Söz konusu ibarede Ahmed Cavid Bey'in Kesbî'den yani Mehmed Haşim Efendi'den talebi üzerine bu takririn tahrir edildiği bilgisi ikisi arasındaki tanışıklık açısından dikkate değer bir karine sağlamaktadır.

Mehmed Haşim' in bu görevde Ali Paşa'nın Anapa' da vefatına (1785) kadar kalmış olduğu anlaşılmaktadır. Ali Paşa ile ilgili anlatımları sırasında kendisini onun adamları içinde Kesbî unvanıyla tanıttığı görülür. Cevdet Paşa'nın kaynakları arasındaki Ahval-i Anapa nüshasında,

48 Haşim Efendi Konya'yı anlattıktan sonra Ereğli'yi tasvir ettiği metinde 1197'de burada bulunduğunu yazar (Seyahatname, TSMK, Hazine, nr. 1564, 90a). Bu durumda onun Ferah Ali Paşa'nın yanına hangi tarihte ulaştığı konusu biraz karışır, fakat bunun o senenin sonlarına rastlamış olması ihtimal dahilindedir.

49 Íbretnüma, s. 79-80. Kahraman Paşa olayı dönemin kroniklerinde haylice yer bulur. Haşim vaktiyle vuku bulan olaylar sırasında hadisenin doğrudan şahidi durumundadır. Bunu da takririnde uzun uzadıya yazmıştır.

50 Kafkasya'daki görevi ve bölge ile ilgili yazdığı eserin Jan Schmidt tarafından araştırmaya konu olduğu belirtilmişti. Schmidt, Leiden'de bulunan nüshayı tanıtıp bununla Topkapı Sarayı'nda mevcut olan metni ve Cevdet Paşa'nın kullandığı meçhul nüshayı karşılaştırır: "Mehmed Hâşim Efendi’s Memorandum", s. 413479; Ahval-i Anapa sadeleştirilmek suretiyle yayımlanmıştır: Kesbî Haşim Mehmet Efendi, Ahvâl-l Anapa ve Çerkes, haz. Mustafa Özsaray, İstanbul 2012. Esere ait bir başka nüsha İstanbul Üniversitesi Kütüphanesi, nr. TY. 5945'te İbretnüma-yı Devlet-i Cavîd adını taşıyan ve aşağıda da belirtileceği gibi müellifimizle ilişkili olduğu anlaşılan eserin içine de derç edilmiştir: vr. 172a-191b.

51 TSMK, Hazine, n. 1564, vrk. 66a. Bu kayıt eserin sadeleştirilmiş şeklinde hayli anlaşılmaz bir tarzda verilmiştir (Haşim Mehmed Efendi, Ahvâl-i Anapa ve Çerkes, s. 146-147). 
Mehmed Haşim'in Ferah Ali Paşa'nın vefatından sonra kendi durumunu açıklayan bilgilere yer verilmiştir. Bu bilgiler temize çekilerek oluşturulduğu anlaşılan TSMK, H. 1564'teki nüshada mevcut değildir ${ }^{52}$. Muhtemelen tıpk1 seyahatnamede olduğu gibi müsvedde tebyiz edilirken bu şahsi bilgiler ya müellifin bizzat kendisi ya da müstensihler tarafindan ayıklanmıştır.

Cevdet Paşa'nın kullandığı nüshaya göre, Ferah Ali Paşa'nın vefatı üzerine yerine yeni bir idareci gelene kadar işlerin halledilmesi için ahali ve ileri gelenler müteveffa paşanın adamlarının ayrılmasını istemezler. Mehmed Haşim de ahalinin talebi üzerine yeni idareciyi beklemek üzere Anapa'da kalır. Fakat yeni muhafız Bicanoğlu Ali Paşa geldiğinde (15 Kasım 1785) onunla geçinemez, hizmet edemeyeceğini anlayarak ayrılmak için izin ister ve İstanbul'a döner. Bu dönüşünün 1785 senesi sonuna rastladığı açıktır. İstanbul'da iken o sırada Âmedi bulunan Ebubekir Râtib Efendi'nin hizmetinde bulunduğu anlaşılmaktadır ${ }^{53}$. Aslen Çorumlu olan İpeklizade Mustafa Paşa Anapa'ya tayin edilince bu yöreyi tanıyan birisine ihtiyaç duyar. Paşanın kendisi gibi Çorumlu olan, Ferah Ali Paşa yanında bulunan ve Haşim Efendi'yi tanıyan birisi, onun adını verir. Mustafa Paşa hemen İstanbul'daki kapı kethüdasına haber yollayarak Râtib Efendi'den onu istetir. Buna önce rıza göstermeyen Mehmed Haşim, Râtib Efendi tarafından ikna edilir ve yeniden Anapa'ya hareket eder ${ }^{54}$. Mustafa Paşa, Cevdet Paşa'nın kaydına göre 1787 sonbaharında Anapa'ya geldiğinde ${ }^{55}$ Haşim Efendi oradadır ve işleri düzenlemekle meşguldür.

Bir süre sonra Anapa'da işler karışır, Köse Mustafa Paşa bölgeye tayin edilir, her iki Mustafa Paşa da durumu değerlendirip Haşim'i yardım talebi ve destek için İstanbul'a

52 Cevdet Paşa kullandığı nüshanın Şeyhülislam Arif Hikmet Beyefendi kütüphanesinde olduğunu belirtir. Bunun müsvedde nüsha olduğu ve temize çekilenlerden daha ayrıntılı bilgiler ihtiva ettiği Cevdet Paşa'nın nakillerinden anlaşılmaktadır. Bu nüshanın akıbeti konusunda ne yazık ki şimdilik bir bilgi edinemedik. Bu nüsha ile ilgili ayrıca bk. Schimdt, aynı makale, s. 414. Keza bk. yukarıdaki dipnot 15.

53 Tosyalı olmak hasebiyle Haşim Efendi ile tanışıklığı olma ihtimali öne sürülmüştür. Schmidt, "Mehmed Hâşim Efendi's Memorandum", s. 417; Ebubekir Râtib Efendi 1779'da âmedci olmuş, 1787'de âmedcilikten silahdar ve sipah kâtibliğine geçmişti (S. Arıkan, "Ebubekir Râtib Efendi”, DİA, X, 277-278; İ. H. Uzunçarş111, "Tosyalı Ebubekir Râtib Efendi”, Belleten, XXXIX/153 (1975), s. 49-76; Fatih Yeşil, Aydınlanma Çağında Bir Osmanlı Kâtibi: Ebubekir Râtib Efendi, İstanbul 2011).

54 Cevdet, Tarih, haz. A. Özcan, III, 259-260'da Haşim Efendi'nin ifadesiyle olay şöyle anlatılır: “... Anapa'ya karîb olduğumuzda şal ve kuşaktan beş altı sancak şeklinde alâmet gösterilip top atarak limana dâhil olduğumuzda henüz Mustafa Paşa gelmemiş idi. Meğer ki ahâli-i kal 'a ile Abaza beyninde husûmet olduğundan üç gün imiş ki ceng ü cidâl olunup kal 'a mahsûrdur deyü haber verdiklerinde dokuz tabyadan onar top atılması içün kaimmakam bulunan Hüseyin Ă̆a'ya haber gönderdim. Derhal o kadar top endahtıyla şenlik izhâr olundukda kabâil tarafindan elçi zuhûr edip selâmlarını ba 'de't-teblîğ bu günlük ceng te'hîr olunsun, top atarak İstanbul'dan çok bayrakl bir sefine ile gelen kimdir ve sebeb-i izhâr-l sürûr nedir bilip ... fakīr iskeleye çıkmadiğımda kabâil halkından birkaç bin âdem istikbâl birle ... hoş geldiniz safâ geldiniz, yümn-i kademler getirdiniz deyü âşinâlıklar ve muhabbetler arz edip kimi binişime ve kimi kürklerime baş urup almak istediklerinde size İstanbul'dan paşa getiriyorum, bunlar anın bende emanetidir deyü redd-i matlûb eyledim..." (Bu bahis TSMK, Hazine, nr. 1564'teki nüshada çok kısa geçiyor ve müellifin kendine ait ifadeleri yer almıyor: krş. vr. 62a-b).

55 Cevdet, Tarih, İstanbul 1309, IV, 43. 
gönderirler. Haşim Efendi’nin bindiği gemi ters rüzgarlarla Amasra’ya yanaşmak zorunda kalır, buranın ahalisi birtakım isteklerde bulunur, onların da arzlarını alıp sonunda İstanbul'a gelir $^{56}$. İstanbul'a geldiğinde ordunun cepheye hareket etmiş olduğunu öğrenip bir şey yapamaz ve muhtemelen bir daha Anapa'ya dönmez (1788) ${ }^{57}$. İstanbul'da iken yeniden ekibi içinde yer aldığı Ebubekir Râtib Efendi’nin hizmetine girmiş olabileceği düşünülebilir.

Bununla beraber Taylesanizade Hafız Abdullah Efendi'nin müderris tayinleri ile ilgili 21 Rebiülevvel 1201 (11 Ocak 1787) tarihli bir kaydında Amasyalı Mehmed Haşim Efendi'nin Elhac Mustafa Ağa dersliğine 200 akça ile müderris tayin edildiğiyle ilgili bir bilgi yer alır ${ }^{58}$. $\mathrm{Bu}$ tarih Anapa'ya henüz gitmeden önceki bir zamana işaret eder. Eğer burada zikredilen şahıs müellifimiz ise o vakit onun İstanbul'a geldiğinde medreseye devam ettiği ve kitabete geçiş yaptığı, oradan da tekrar müderrislik talebinde bulunduğu farz edilebilir. Fakat bu hususta isim benzerliği dışında kesin bir şey söylemek mümkün değildir. Zira aynı yılın sonlarında Haşim Efendi Anapa'dadır.

Mehmed Haşim Efendi'nin İstanbul' da iken kitabetini sürdürmüş olması mümkündür. 1203 (1788-89) yılında Ege adalarında dolaştığı seyahatnamesindeki bilgilerden anlaşılmaktadır. Fakat hangi sıfatla böyle bir seyahate çıktığı hakkında bilgi yoktur. Yazdıklarından anlaşılan husus buralarda maliye kâtibi olarak vergi işleri için bir nevi teftiş veya görevlendirme neticesi bulunmuş olduğu yönündedir. Özellikle Sakız adasını çok uzun anlatması bu anlamda dikkat çekicidir ve bunlar canlı bir görgü şahidinin kaleminden çıkmış notlardır ${ }^{59}$.

Seyahatnamedeki bilgilere nazaran 1206'da (1792) kitabetten tanıdığı ve hakkında sitayişle bahsettiği Süleyman Feyzi Efendi/Paşa'nın yanındadır. Süleyman Feyzi Paşa'nın Erzurum valiliğinden azli ve İstanbul'a doğru yola çıkışı, ardından da Halep eyaletine tayini oradaki faaliyetleri konusunda hayli teferruatlı bilgiler vermesi bu anlamda dikkat çeker. Anlattığı yerler de bu güzergâhta bulunmaktadır (Erzurum-Trabzon güzergâhı, Sinop, Kastamonu, Ankara). Muhtemelen Halep'te iken Lübnan kıyılarını ve oradaki Dürzilerin ve diğer toplulukların adetlerini öğrenip bunları tafsilatıyla eserine derç etmiştir. İbretnüma' da ise 1206 Şevvalindeki (Mayıs-Haziran 1792) orduyla sancak-1 şerifin avdeti münasebetiyle yapılan merasimi bir görgü şahidi gibi anlatması ${ }^{60}$ yukarıdaki bilgilerle karşılaştırıldığında Haşim Efendi'nin İstanbul'a gelip sonra yeniden Süleyman Feyzi Paşa'nın yanına gittiğini düşündürürse de bu hususta kesin bir kanaate varmak mümkün gözükmez. Ancak İbretnüma'daki bilgiden hareketle 1794'te Halep'te Halep hazinesiyle ilgili bir yolsuzluğun

56 Sinop ve Amasra ile ilgili bilgiler ayrıca İbretnüma-yı Devlet-i Cavid adıyla bilinen nüshada da bulunur. İ.Ü. Ktp., nr. TY 5945, 195b-196a.

57 Cevdet, Tarih, IV, 43.

58 İstanbul'un Uzun Dört Ylll, Taylesanizade Abdullah Efendi Tarihi, haz. F. M. Emecen, İstanbul 2003, s. 249.

59 TSMK, Hazine, nr. 1564, vr. 12b-39a.

60 İbretnüma, s. $324 \mathrm{vd}$. 
soruşturmasıyla ilgilenmiş olduğuna dair verdiği bilgi ${ }^{61}$, Halep bağlantısı bakımından seyahatnamedeki anlatılanlarla bir ölçüde örtüşür görünmektedir.

1792-94 yıllarına tekabül eden Halep’teki görevinden sonra İstanbul'a döndüğü açıksa da bundan sonra ne gibi vazifeler icra ettiğine dair bilgiler yoktur. Yine seyahatnameye göre 1797 Ocağında Atina'da bulunmuş olma ihtimali yüksektir. Atina’yı anlattığı kısımda hayli canlı tasvirler yapar; fakat buraya hangi görevle gittiğini açık şekilde belirtmez ${ }^{62} .1212$ Ramazan'ında (Şubat 1798) Sivas'ta olduğuna dair seyahatnamesinde küçük bir atıf vardır ${ }^{63}$. Eserlerini hazırladığı tarih ise 1213 (1798-1799) yılıdır, bu sırada İstanbul'da bulunduğu söylenebilir.

Mehmed Haşim'in bu tarihten sonraki hayatına dair bilgi yoktur, hemen bütün eserlerinin son telif tarihi en geç 1799 ile sınırlanmaktadır. İstanbul'da bulunduğu sıralarda Ahmed Cavid Bey ile yakın temasta olduğu eserlerinden anlaşılmaktadır. Keza Reisülküttab Ebubekir Râtib Efendi’yle de münasebetlerini sürdürüyor olması ihtimal dahilindedir. Râtib Efendi'nin azli ve idamı sırasında onun yakın adamları arasında adı geçen Amasyalı Haşim Efendi'nin müellifimiz ile ilgisi hakkında kesin bir şey söylemek zordur. Ebubekir Râtib Efendi 14 Safer 1211'de (19 Ağustos 1796) azledilince, yakın adamlarından müderris Haşim Efendi ile Silahdar Kalemi Baş halifesi Mestan Efendi'nin Hanya'ya sürüldüğü bilgisi dikkat çeker ${ }^{64}$. Eğer bu Haşim Efendi ile müellifimiz Mehmed Haşim aynı şahıslar ise o vakit Mehmed Haşim Efendi'nin Halep'den döndükten sonra Râtib Efendi'nin himayesine girdiği ileri sürülebilir. Bursalı Mehmed Tahir, Haşim Efendi’nin sürgün olarak bulunduğu Hanya'da vefat ettiği kaydını düşer, ama bu bilginin kaynağı tesbit edilememiştir ${ }^{65}$.

Bununla beraber Haşim Efendi'nin izlerine yukarıda temas edildiği üzere 1797 Ocağında Atina'da, 1798'de de Sivas'ta rastlanmakta olması, ayrıca eserlerini de 1799' da tamamlamış bulunması bu durumu meşkûk hale getirir. Fakat yine de seyahatnamesine Girit'ten başlaması ve üstelik burada bizzat bulunduğuna dair ifadesi Girit’te sürgün vesilesiyle bir süre ikamet

61 Konu Halep'te bulunan tercümanların vergileriyle alakalıdır. Sayıları hayli fazla olan tercümanlar (1.500 nefer) ve hizmetlilerin "Haleb'in emtia ve dühan gümrüklerine hadden birûn hasâret" eyledikleri bildirilince merkezdeki kalemden kayıt/berat defterleri taleb edilmiş, Mehmed Haşim’de bu beratları Haleb’e getirip kontrol edildiğinde bunların aslında yol hükümleri olduğu, asılları itibarıla Maruni ve Süryani raiyyet ve raiyyet oğulları oldukları, beşer-onar senelik cizye kağıtlarının olmadığı tesbit edilmiş. Kaybı önlemek için cizye kağıtları dağıtılmıştır (İbretnüma, s. 36-37).

62 Burada 1797 yılı Kanunusanisi'nin yedisi olarak tarihi miladi usule göre vermiştir (TSMK, Hazine, nr. 1564, vr. 116a).

63 Seyahatname, müsvedde nüsha, s. 170.

64 Ahmed Vasıf, Mehâsinü'l-âsâr ve Hakaikü'l-ahbar, haz. H. Sarıkaya, İstanbul 2017, s. 211-212. Ancak Nuri Tarihi'nde Amasyalı Haşim'in Limni'ye, Mestan'ın Hanya'ya sürüldüğü bilgisi vardır (Vak'anüvis Halil Nuri Bey, Nûrî Tarihi, haz. Seyyid V. Toprak, Ankara 2015, s. 426; keza Cevdet, Tarih, VI, 231). Bu durumda Vasıf'ın Nuri Tarihi'ni kaynak olarak kullanırken bir atlama yapmış olma ihtimali doğar. F. Yeşil de Nuri Tarihi ve Cevdet Tarihi'ndeki bilgiyi esas almıştır: Ebubekir Râtib Efendi, s. 435.

65 Sicill-i Osmanî, IV, 624. 
etmiş olma ihtimalini kuvvetlendirir. Nitekim şu beyanı Girit’te Kandiye'de bulunduğunun delili gibidir: "Bundan başka bu havâlîlerde mahkûk mühürler bulunur. Henüz hakkâk elinden çıkmış gibidir ve Ya 'kub ve İsma îl ve Yusuf ve Şu'ayb ve Musa ve Hasbiyullah gibi hakk ü tahrîr olunmuşdur ve Havâssı vardır deyü zengin olmak içün isti 'mâl ederler. Bu fakīr-i pürtaksîr mâlik olamadım. Ekser taşları hacer-i Süleymanîdir." ${ }^{66}$ Seyahatnamesindeki tarihlerle karşılaştırıldığında Mehmed Haşim Efendi’nin Girit macerasının kısa sürdüğü düşünülebilir.

Bunların dışında Câbi Tarihi'nde de miri kâtibi iken müderris olan Haşim Bey’den söz edilmesi bir başka dikkat çekici bilgi olarak karşımızda durmaktadır. Câbi'nin onu hem kâtib hem de müderris olarak tanımlaması, Taylesanizade ve Vasıf'ta yer alan kayıtlarla bir yerde örtüşür görünmektedir. Câbi’nin yazdığına nazaran Haşim Bey, İzmir kadı naibliğine yollanmış; fakat burada ancak beş ay görev yapabilmiş, oradaki önde gelen zevat ile geçinemediği, döneminde yangınlar çıktığı ve huzursuzluk sebebiyle niyabetten azledilmiştir. Câbi bu hadise için 13 Ramazan 1226 (21 Eylül 1811) tarihini vermektedir ${ }^{67}$. $\mathrm{Bu}$ durum yukarıda da belirtildiği üzere kitabetten medreseye geçme halini bir ölçüde açıklığa kavuşturur gibiyse de bu şahısların aynı kişiyi gösterme ihtimali, tarihin hayli geç olduğu da hesaba katılırsa, pek mümkün değildir. Haşim Efendi'nin vefatı için eserlerini telif ettiği 1213/1799 tarihinden sonrasını esas almak ve bu tarihten sonra pek fazla yaşamadığını düşünmek uygun gibi görünürse de aşağıda temas edileceği üzere İbretnüma-yı Devlet-i Cavid başlıklı nüshanın Mehmed Haşim ile alakası olduğu hesaba katılırsa, bu eserde yer alan son kayıtlardan hareketle 1219 ilkbaharında (1804 yılı Nisan-Mayıs) hayatta olduğu çıkarılabilir. Bu tarih Ahmed Cavid Bey'in vefatından bir yıl sonrasına tesadüf eder. Bu nüshadaki bilgiler Mehmed Haşim'in son yıllarını İstanbul'da geçirdiğini açık şekilde gösterir. Zira özellikle Napolyon'un Mısır'ı işgali, Akka direnişi hakkında duyduğu haberleri geniş şekilde anlatır ve bunları "istima" ettiğini belirtir; bu arada müşahede ettiği İstanbul'daki bazı hadiseleri kenar notlarında zikreder ${ }^{68}$.

Açık olarak bu son eser muvacehesinde Haşim Efendi ile ilgili bilgileri 1804 tarihine kadar takib edebilmek mümkün olmuştur, bundan sonrası için herhangi bir kayıt tesbit edilememiştir $^{69}$. İbretnüma nüshalarındaki bilgiler onun kalemle ilgisini kesmediğini ve birçok raporu, müzakere kaydını, irad ve masraf defterlerini, hatt-ı hümayunları, elçi raporlarını, anlaşma mükaleme kayıtlarını gördüğünü ve bunları eserine derç ettiğini gösterir. Bütün bu bilgileri topluca ele aldığımızda Mehmed Haşim'in 1746 tarihinden itibaren en azından 1805'e kadar hayatının bazı safhalarını takip etme imkânı olduğunu söyleyebiliriz.

66 TSMK, Hazine, nr. 1564, vr. 2a.

67 Câbi Tarihi, haz. Mehmet Ali Beyhan, Ankara 2003, s. 788-789.

68 İbretnümâ-yl Devlet-i Cavid, İ.Ü. Ktb., TY. 5945, 210a-217b.

6915 Safer 1223 (14 Nisan 1808) bir sicil kaydında da kadı Seyyid Haşim Efendi b. Seyyid Elhac Eyyüb'ün diğer bir kadı Musa Efendi ile olan alacak-verecek davası yüzünden mahkemelik olduğu görülürse de bunun müellifimizle alakalı olma ihtimali baba adının farklı olması hasebiyle yoktur: Ístanbul Kadı Sicilleri, İstanbul Mahkemesi, İstanbul 2019, c. 85, s. 270 (31b). 
Seyahatnamesindeki gezip dolaştığı tahmin edilen yerlerin bazılarında çeşitli vesilelerle birtakım görevler icra etmiş olması pekâlâ mümkün görünmektedir. Bu gibi taşra görevlerinin çoğunun kapılandığı paşaların yanında onların kâtibi olarak gerçekleştiği de söylenebilir. Kaleme aldığı/derlediği eserler ise Mehmed Haşim'in entelektüel şahsiyetini ve birikimini ortaya koymak bakımından hayli belirleyicidir.

\section{Mehmet Haşim’in Eserlerine Dair Bazı Yeni Tesbitler}

Mehmed Haşim'in yukarıda temas ettiğimiz Ahval-i Anapa ve Seyahatnamesi dişında diğer çalışmaları itibarıyla İbretnüma-yı Devlet adlı eseri ve Divanı'nın mevcut olduğu, kaleme aldığı takrirlerinin başka eserlerin içinde bulunduğu ve hatta onun yazdıklarından istifadeyle farklı müstakil eserlerin vücuda getirildiği anlaşılmaktadır. Ortaya koyduğu telifatı itibarıyla yazdıklarının değerlendirilmesi ayrı bir çalışmayı gerektirir. Burada ana hatlarıyla hayatının safhaları çerçevesinde tanıttığımız çalışmaları dışında ona mal edilebilecek eserlere dair bazı tesbit notlarına yer vermek istemekteyim.

Öncelikle Mehmed Haşim'in kitabette iken çeşitli raporlar kaleme aldığına şüphe yoktur. Íbretnüma'da yer verdiği irad-masraf kayıtları sefer harcamaları ile ilgili listeleri bizzat görüp eserine derç ettiğinden söz edilmişti. Öte yandan mevcut iki nüshasıyla bilinen Íbretnüma adlı eseri bu kabil farklı konuları içine alan bir derleme niteliği taşımaktadır. Keza Cavid Bey adıyla kataloglarda geçen bir başka İbretnüma-yı Devlet adlı nüshanın da hem diğer iki nüshayla hem de Mehmed Haşim ile ilgisi olma ihtimali yüksektir. Eser üzerine çalışanlar bunun Kesbi’ye ait İbretnüma adlı eserden farklı olduğunu ileri sürerler ${ }^{70}$. Fakat içinde yer alan olayların ve bilgilerin derlenmesinde Kesbî yani Mehmed Haşim'in açık izleri dikkat çeker. Özellikle Ferah Ali Paşa'nın faaliyetlerini anlattı̆̆ı ve müstakil bir metin olarak iki nüshasına rastlanan risalenin bir başka metni de bu eserin içine eklenmiş bulunmaktadır ${ }^{71}$. Böylece Ahmed Cevdet Paşa'nın Tarih'i içinde ${ }^{72}$ yer alan metin ile birlikte dört nüsha ortaya çıkmış olmaktadır. Bunun dışında Mehmed Haşim’in Hotin ile ilgili geniş takririnin farklı ifadelerle yer yer de ihtisar edilerek buraya derç edildiği görülür ${ }^{73}$. Haşim'in seyahatnamesindeki bazı bilgilerle örtüşen bahisler de bu nüshada mevcuttur. Mesela Hotin'in acibesi kısmı ${ }^{74}$, Çamlıca adası hakkında bilgi hemen zikredilebilir. Ayrıca burada

70 İbretnüma, s. XXXI. Ayrıca bu nüsha üzerine müstakil tanıtımda da farklı eser olduğu yorumu hakimdir. A. Aslantürk-F. Bozkurt, “18. Yüzyılın İkinci Yarısına Dair Önemli Bir Osmanlı Tarihi: İbretnüma-yı Devlet-i Câvid”, Sosyal ve Kültürel Araştırmalar Dergisi, II/3 (2016), s. 155-194.

71 İ.Ü. Ktp. nr. TY. 5945, 171b-175a ve 186b-203a. Konu başlığ1 şöyledir: "Hikâyât-1 Ferah Ali Paşa Fâtih-i Çerakise Bâni-i Kal'a-i Anapa, sene 95”. Hayli ihtisar edilmiş şekilde anlatılan bu bahiste müellifin diğer nüshalardakinin aksine adını hiç vermediği görülür. Ayrıca buradaki başlık sistemi de Mehmed Haşim'in diğer eserlerindeki tarzla benzeşir, "Garibe/Garibesi” başlığı altında Seyahatname ve diğer eserlerindeki bilgi notu şeklini burada da muhafaza eder.

72 Cevdet, Tarih, III, haz. A. Özcan, s. 177-261.

73 İ.Ü. Ktp., nr. TY. 5945, 78a-79a.

74 İ.Ü. Ktp., nr. TY. 5945, 77a. 
ilk görevlerinden biri olarak İsakçı’ya gidişiyle alakalı doğrudan birinci şahıs ifadesi de dikkat çeker: "Bu fakir 1182 senesinde 60 nefer süvari ile İsakçı’ya gider iken.."”75. Bir başka yerde Anadolu kıyılarından İstanbul'a giderken Sinop'a uğradığını, burayı gezdiğini anlatır; Süleyman Feyzi Paşa'nın buradaki icraatına, yaptırdığı tahkimata temas eder; oradan uğradığı Amasra' daki ve Karadeniz Ereğlisi'ndeki durumu bir müşahid gözüyle zikreder ${ }^{76}$. Bu bilgiler hem Cevdet Paşa'nın kullandığı Ahval-i Anapa nüshası hem de seyahatnamedeki bahislerle benzerlik gösterir. Ayrıca Halep'teki kıtlık ile Sakız seccadesi bahisleri seyahatnamedeki bilgilerle açık şekilde örtüşür ${ }^{77}$.

Bu bakımdan İbretnüma-yı Devlet-i Cavid başlıklı eserin de bir derleme olduğu ve diğer iki İbretnüma nüshasındaki bazı boşlukları doldurduğu açıktır. Bu sonuncu eseri ayrı bir nüsha gibi görüp başka bir müellife atfetmek için belirleyici bir delil yoktur. Aksine Mehmed Haşim'i işaret eden sarih karineler söz konusudur ve ayrıca bunlar esasen Cavid Bey ile Mehmed Haşim arasındaki yakınlığın bir başka örneği olarak karşımızda durmaktadır ${ }^{78}$.

Öte yandan yine Mustafa Kesbî’ye atfedilen bir başka nüsha daha tesbit edilmiştir. Bu nüsha daha düzgün ve kısaltılmış, yer yer sistematize edilmiş şekilde olup 1768 seferi başlangıcından itibaren olayları anlatır, Kesbî Mehmed Haşim Efendi'nin İbretnüma nüshalarıyla da benzerlikler arz eder. Kesbî gibi maliye kâtiblerinden biri olan Zekeriyazade Mehmed Said'e atfedilen bu eserin İbretnüma nüshalarıyla ilişkisi mevcutsa da müellifinin kendinden bahsettiği yerlerin çıkarıldığı ve daha muhtasarca bilgilere yer verildiği görülür. Bu anlamda söz konusu nüshanın ya Kesbî yahut başlıkta adı geçtiği üzere onun eserlerinden hareketle Zekeriyazade tarafindan düzenlenmiş olabileceği ihtimalini göz $\operatorname{ard}_{1}$ etmemek lazımdır ${ }^{79}$.

75 İ.Ü. Ktp., nr. TY. 5945, 201a; krş. İbretnüma, s. 86 (Burada peksimet meselesini anlatırken İsakçı’yı zikreder).

76 İ.Ü. Ktp., nr. TY. 5945, 195b-196a.

77 İ.Ü. Ktp., nr. TY. 5945, 200a'da kenar notunda “Kaht u galâ-yı Haleb” başlığı aynen Seyahatname'de bulunur: TSMK, Hazine, nr. 1564, 62b. Keza Sakı adasındaki seccade bahsi benzeri ifadelerle her iki metinde yer almaktadır: İ.Ü. Ktp., nr. TY. 5945, 208b; krş. TSMK, Hazine, nr. 1564, 18 a.

78 Eserin son kısımlarındaki bahisler Ahmed Cavid Bey'in vefatından sonraki olayları içine alır. Bu bakımdan esere onun adının verilmiş olmasında Mehmed Haşim'in rolü olduğunu varsaymak mümkündür. Söz konusu eserdeki bahislere bakıldığında, Ahmed Cavid'in Hadika-i Vekayi' (nşr, A. Baycar, Ankara 1998) adlı eserindeki benzeri olayların anlatım şekliyle hiçbir irtibatı görülmez. Derlemenin Haşim'in kaleminden çıkmış olması ihtimalini bu durum kuvvetli biçimde teyid eder.

79 Bu eser TSMK, H. 1572'de bulunmakta olup yüksek lisans tezi olarak hazırlanmış ve eser Kesbî’ye nisbet edilmiştir (Serkan Osmanlıoğlu, Mustafa Kesbî'nin 1768-1774 Harbi Vekayii, Marmara Üniversitesi Türkiyat Araştırmaları Enstitüsü, İstanbul 2017). İbretnüma nüshalarıyla yapılan karşılaştırmalarda benzerlikler tezi hazırlayan tarafından gösterilmiş ve bunun Cavid'e atfedilen nüsha yanında İbretnüma nüshasıyla da mukayesesine çalışılmıştır. Bu bilgilerin Kesbî’ye ait olma ihtimali şüphesiz yüksektir. Fakat notların düzgün şekilde tanzimini bir başkasının yapmış olma ihtimalini de hatırdan "dûr etmemek" lazımdır. Öte yandan 1768 seferinin ilk safhalarıyla ilgili başka müelliflere mal edilen risale-gûne eserlerin varlığını tesbit etmek mümkündür. Bunların ehemmiyetli bir kısmı tez olarak hazırlanmıştır: Hilal Yavuz, Tarih-i Sefer-i Rusya'ya Göre 1768-1774 Osmanlı-Rus Savaşı, Karadeniz Teknik Üniversitesi, Yüksek Lisans Tezi, Trabzon 2012; Ahmet Özcan, Kethüda Said Efendi Tarihi ve Değerlendirmesi, Kırıkkale Üniversitesi, Yüksek Lisans Tezi, 1999 (Bu eserin bir başka nüshası yapılan bu tez görülmeksizin yüksek lisans tezi olarak hazırlanmıştır: Abdullah Altın, Said b. Halil İbrahim' in Tarih-i Sefer-i Rusya Adlı Eseri, Erciyes Üniv. Sosyal Bilimler Enst., 2006). Ayrıca bu dönemle ilgili diğer risaleler: Ahmet Fakazlı, Azizzade Hüseyin Ramiz Efendi'nin Zübdetü'l- 
$\mathrm{Bu}$ sonuncusu hariç zikredilen İbretnüma nüshalarındaki farklı konuların bir araya getirilmesiyle yapılan derleme tarzı, bir ölçüde Ahmed Cavid Bey'in Müntehabatı ile büyük benzerlik arz eder. Mehmed Haşim, İbretnüma'nın sonunda kendi kalemiyle Ahmed Cavid Bey’in, kitaplarının bir bölüm satılan ve dağıtılan Saray kütüphanesinin yeniden tanzimiyle görevlendirilmesini, buranın onun nezaretinde olmasını bildiren bir takrire dahi yer vermiştir ${ }^{80}$. Keza İbretnüma' da kendi eserlerine yaptığı atıflar da vardır. Bunlar arasında seyahatnamesine yaptığı atfı tesbit etmek mümkündür: Kırım hanlığına tayin münasebetiyle “Âmeden-i Kırım Giray Han” başlığından sonra biraz bilgi verip yeni bir başlığa geçerken “Garîbesi Törehât nâm kitâbda zikr ü beyân olunduğu üzere” diye seyahatnameye gönderme yapar $^{81}$. Ayrıca Çerkez diyarıyla ve Kırım ile ilgili bazı bilgiler de seyahatnamesiyle ilişkili görünür ${ }^{82}$. Ahval-i Anapa adlı eserine yine İbretnüma' da bazı bahislerde dolaylı göndermeler yer alır. Ferah Ali Paşa'dan söz ettiği bir yerde, “... müşârün-ileyhin evsâfi hakkında tahrîr olunan evrakda mastûr ve mukayyeddir" ifadesiyle Ahval-i Anapa'ya atıf yapar ${ }^{83}$. Keza başka bir yerde “... müşârün-ileyhin evsâfi hakkında olan başkaca kitâbda bast u beyân olunmuşidi...” denerek aynı eser bir kere daha zikredilir ${ }^{84}$.

Öte yandan yukarıda da bahsedildiği gibi Mehmed Haşim büyük bölümünü derleme olarak hazırladığı nüshalarda yer alan raporlar, risaleler, takrirler kaleme almıştır. Bu arada ona ait olması kuvvetle muhtemel olan bazı risalelerin anonim şekilde kütüphane veya arşivlerde bulunması pekâlâ mümkündür. Böyle bir örnek vaktiyle Ç. Uluçay’ın tanıttığı, sonra C. Orhonlu tarafından yayımlanan teşkilata dair bir risale vesilesiyle ortaya çıkar ${ }^{85}$. C. Orhonlu tarafından "Risâle-i Terceme" adıyla yayımlanan, müellifi tesbit edilemeyen bu küçük eserin, Mehmed Haşim tarafından kaleme alındığı anlaşılmaktadır. Zira metinde geçen bazı bilgiler, Mehmed Haşim'e ait eserlerdekilerle yer yer örtüşür. Mesela risalede “ez-cümle Divân-1 Rum ki şehr-i Sivas demekdir, yedi sancak bir mansıbdır” ibaresi başlık halinde seyahatnamesinin Sivas kısmında yer alır ${ }^{86}$. Ayrıca Hekimoğlu Ali Paşa'nın Sivas’ta iken askerinin durumu ve zahire tedariki konusundaki bilgileri karşılaştırdığı kısım, yine seyahatnamede Hekimoğlu

Vâkı'at Adlı Eserinin Tahlil ve Tenkitli Metni, Fatih Sultan Mehmed Vakıf Üniv., Yüksek Lisans Tezi, 2017; Engin Çetin, Mehmed Emin Recai'nin 1768-1774 Osmanlı Rus Savaşına Dair Mecmuası, Marmara Üniv. Türkiyat Araştırmaları Enstitüsü, Yüksek Lisans Tezi, 2017.

80 İbretnüma, s. 521-522.

81 İbretnüma, s. 75. Naşir bunu yanlışlıkla Nurhat, Turhat gibi okumuş, kitap hakkında bilgi bulunmadığını notta belirtmiştir. Bu kelime türrehât şeklinde okumaya müsait değildir. Anlam itibarıyla belki maksada uyar gibi gözükür ama yazılış tarzı turre (ثر ) şeklinde değildir.

82 İbretnüma, s. $11 \mathrm{vd}$.

83 İbretnüma, s. 129.

84 İbretnüma, s. 445.

85 Bu risalenin TSMA, N. E. 12365 'te bulunduğu belirtilmiş olup Ç. Uluçay tarafından kullanılmış (18. ve 19. Yüzyıllarda Saruhan'da Eşkiyalık ve Halk Hareketleri, İstanbul 1957, s. 12, 35-37, 49) ve C. Orhonlu da bu bilgiden hareketle risaleyi yayımlamıştır: "Osmanlı Teşkilatına Aid Küçük Bir Risâle”, Belgeler, IV/7-8 (Ankara 1967), s. 39-47. Ancak bu numarada risalenin orijinal nüshası yoktur. Muhtemelen risalenin kayıt numarası bilahıre değiştirilmiştir.

86 Seyahatname, 71b'de: "Divân-1 Rum yani Sivas demekdir...". 
Ali Paşa'ya atfen benzeri anlamda zikredilir8 ${ }^{87}$. Keza daha açık ifadeler Sakız, İstanköy ve Rodos'daki portakal ve limon sevkiyatıyla ilgili kayıtlarda görülür. Seyahatnamede neredeyse aynı ayrıntılar benzeri ifadelerle yer alır ${ }^{88}$. Yine voyvodaların ticareti ile ilgili bahiste kullanılan Eflak ve Boğdan'dan “yamak çıkarmak” tabiri, aynen seyahatnamede yer alan ve hayli uzun bir bahis olan Eflak kısmında zikredilmiştir ${ }^{89}$. Bu bakımdan Mehmed Haşim'in teşkilata dair görüşlerini topladığg bu küçük eserinin beraber çalıştığı paşalara veya yüksek bürokratlara hitaben kaleme alınmış olma ihtimali yüksektir. Onun bunun gibi daha başka risalelerin sahibi olduğunu düşünmemek için de bir sebep yoktur. Bu risalenin yazılış tarihinin, Hekimoğlu Ali Paşa'nın Sivas valiliğinden (hicri 1157/1746) 40-50 yıl sonrasına yani 1790’lı yıllara rastladığı -kendi beyanından hareketle- ortaya çıkmaktadır.

Bunların dışında Mehmed Haşim'in Kesbî mahlasıyla şiirleri olduğu ve bunları Divan'ında topladığından söz edilmişti. Divan' da yer alan bazı şiirlerine diğer eserlerinde de yer verdiği anlaşılmaktadır. Mesela seyahatnamedeki bir gazeli Divan'ında da aynen mevcuttur ${ }^{90}$. Seyahatnamede başka pek çok şiir kaydetmiştir, özellikle de dönemin meşhur şairleri içinde öne çıkan Hasib Efendi' den uzun uzadıya şiirler aktardığg görülür ${ }^{91}$. Seyahatnamede yer alan söz konusu gazelinde Kesbî Mehmed ismini yan kısma eklemiş ve bu adların ebced hesabıyla karşılığını da yazmıştır. Bu durum Divan sahibinin adının Kesbî Mehmed olduğunu itiraza mahal vermeksizin kesinleştirecek önemli bir delil teşkil eder.

Netice olarak XVIII. asrın son yarısında yaşayan ve bugüne kadar sadece Ferah Ali Paşa'nın kâtibliğini yaparken yazdığı eseriyle tanınan Mehmed Haşim’in bilinen ve sıklıkla kullanılan başka eserlerin de müellifi olduğu anlaşılmaktadır. Entelektüel kimliğini bilhassa seyahatnamesindeki değerlendirmelerle gösteren Haşim Efendi’nin yazdıklarının dönemin atmosferi içinde dikkatlice yapılacak olan incelemesi, yeni bilgilerin gün yüzüne çıkmasına vesile teşkil edecektir. Ayrıca onun hakkında başka belge ve bilgilerin zuhur etmesi de

87 Orhonlu, "Osmanlı Teşkilatına Aid Risale”, s. 41; krş. Seyahatname, 72a. Burada çok özel bir bilgi olarak her iki metinde de "şimdiki Sivas valilerinin bin iki yüz yem-i şair vermeğe kudretleri olmadığı" bahsi söz konusudur.

88 Her iki metinde de ortak ifade, "Sakız, İstanköy ve Rodos’ta limon ve portakalın bin adedinin üç paraya mübaya'a olunduğu ve altı para da hammaliye verilerek iskeleye taşındığıı"dır (Orhonlu, "Osmanlı Teşkilatına Aid Risale", s. 43; krş. Seyahatname, 22b).

89 Seyahatname, 141a; krş. Orhonlu, "Osmanlı Teşkilatına Aid Risale”, s. 44.

90 İ.Ü. Ktb., nr. TY. 838'de yer alan Divan'ın kapağı üzerinde “Gazeliyât-1 Kesbî Efendi” ibaresi vardır. Zahrında da "Divan-1 Kesbî” yazısı okunur. Hatime kısmında 25 Cemaziyelevvel 1203 (21 Şubat 1789) tarihi yer alır, 52 varaktır ve 120 gazelden oluşur. Seyahatnamede yer verdiği bir gazeli aynen Divan'da da bulunur (TSMK, Hazine, nr.1564, 110b-111a; krş. Divançe-i Kesbî, Yüksek Lisans Tezi, 74 numaralı gazel, vr. 31a-b).

91 Burada Kesbî kendisinin bir mecmuası ve bir de divanının bulunduğunu belirten mısralara yer vermiş, ayrıca dönemin önemli şairlerinden Hayrabolulu Hasib Efendi’yi de asrın Nabi’si gibi tanıtmıştır (Divançe-i Kesbî, Y. Lisans tezi, s. 141, 146). Seyahatnamesinde Hasib Efendi’nin şiirleri için bk. TSMK, Hazine, nr. 1564, 97b-98a, 100a-b, 101b-104a. Hasib Efendi hakkında bilgi veren ve vefatına düşürülen tarihi kaydeden Mehmet Haşim'in onunla yakın dostluğu olduğu anlaşılır. Hasib Efendi için bk. Ramazan Ekinci, "Hayrabolulu Hasib ve Eserlerinden Örnekler”, Yeni Türkiye, 67/2015, s. 2373-2386; Hayrabolulu Hasîb Dîvânı, haz. R. Ekinci- S. Donuk, İstanbul 2015. 
muhakkaktır. Bu makalede Mehmed Haşim'in özellikle İbretnüma-yı Devlet adlı eserin gerçek yazarı olduğu noktası, meçhul kalmış hayat hikayesiyle birlikte açıklığa kavuşturulmaya çalışılmıştır. Eserleri üzerinde yapılacak derin/tahlili değerlendirmeler ve katkılar ise bu dönemin tarihçiliğini "indeksleme ve nakletme" mantalitesinden ziyade tahlili bakışla ve alt okumalarla, hizip bağlarıyla ve sosyal muhitleriyle ele alabilecek yeni araştırmacılarını beklemektedir.

Hakem Değerlendirmesi: Dış bağımsız.

Çıkar Çatışması: Yazar çıkar çatışması bildirmemiştir.

Finansal Destek: Yazar bu çalışma için finansal destek almadığını beyan etmiştir.

Peer-review: Externally peer-reviewed.

Conflict of Interest: The author has no conflict of interest to declare.

Grant Support: The author declared that this study has received no financial support.

\section{Kaynakça/References}

Ahmed Badi, Riyâz-ı Belde-i Edirne, haz. N. Adıgüzel-R. Gündoğdu, II/2, İstanbul 2014.

Ahmed Cavid Bey, Hadika-i Vekayi, haz. Adnan Baycar, Ankara 1998. , Müntehabât, haz. Adnan Baycar, İstanbul 2004.

Ahmed Cevdet Paşa, Tarih-i Cevdet, I, haz. Mehmet İpşirli, Ankara 2018; III, haz. Abdülkadir Özcan, Ankara 2018; IV, İstanbul 1309.

Ahmed Vasıf, Mehâsinü'l-âsâr ve Hakaikü'l-ahbar, haz. Hüseyin Sarıkaya, İstanbul 2017.

Altın, Abdullah, Said b. Halil İbrahim'in Tarih-i Sefer-i Rusya Adlı Eseri, Erciyes Üniversitesi Sosyal Bilimler Enstitüsü, Yüksek Lisans Tezi, 2006.

Arıkan, Sema, "Ebubekir Râtib Efendi”, DIA, X, 277-278;

Aslantürk, Ahmet - Fatih Bozkurt, "18. Yüzyılın İkinci Yarısına Dair Önemli Bir Osmanlı Tarihi: İbretnümayı Devlet-i Câvid”, Sosyal ve Kültürel Araştırmalar Dergisi, II/3 (2016), s. 155-194.

Aydın, Mahir, "Şeyhülislam Arif Hikmet Beyefendi”, Belleten, LIV/209, Ankara 1990, s. 245-261.

Ayvansarayî, Vefeyât-ı Selâtin ve Meşâhir-i Ricâl, haz. Fahri Ç. Derin, İstanbul 1978.

Babinger, F., Osmanlı Tarih Yazarları ve Eserleri, trc. Coşkun Üçok, Mersin 1992.

Beydilli, Kemal, “Selim III”, DIA, XXXVI, 420-425.

Bursalı Mehmed Tahir, Osmanlı Müellifleri, III-IV, İstanbul 1342.

Câbi Tarihi, haz. Mehmet Ali Beyhan, Ankara 2003.

Çetin, Engin, Mehmed Emin Recai'nin 1768-1774 Osmanlı Rus Savaşına Dair Mecmuasl, Marmara Üniversitesi Türkiyat Araştırmaları Enstitüsü, Yüksek Lisans Tezi, 2017.

Divançe-i Kesbî: Transkripsiyon, Metin, Sözlük, Indeks, haz. Zehra Karakaş, Dumlupınar Üniv. Sosyal Bilimler Enstitüsü, Kütahya 2000.

Doğan, Muzaffer, Osmanlı Devletinde İçişlerinin Yönetimi: Sadaret Kethudalı̆̆l, 1730-1836, Ankara 2016. 
Ekinci, Ramazan, "Hayrabolulu Hasib ve Eserlerinden Örnekler”, Yeni Türkiye, 67/2015, s. 2373-2386.

Fakazlı, Ahmet, Azizzade Hüseyin Ramiz Efendi'nin Zübdetü'l-Vâkı'at Adlı Eserinin Tahlil ve Tenkitli Metni, Fatih Sultan Mehmed Vakıf Üniversitesi, Yüksek Lisans Tezi, 2017.

Fedakar, Cengiz, “Anapa”, DİA, Ek I, s. 94-95. , Kafkasya'da Imparatorluklar Savaşı: Kırım'a Giden Yolda Anapa Kalesi (1781-1801), İstanbul 2014.

Hayrabolulu Hasîb Dîvânı, haz. R. Ekinci- S. Donuk, İstanbul 2015.

Hilal Yavuz, Tarih-i Sefer-i Rusya'ya Göre 1768-1774 Osmanlı-Rus Savaşı, Karadeniz Teknik Üniversitesi, Yüksek Lisans Tezi, Trabzon 2012.

İbretnüma-yı Devlet-i Cavid, İstanbul Üniversitesi Ktb. nr. TY. 5945.

İstanbul'un Uzun Dört Yıll, Taylesanizade Abdullah Efendi Tarihi, haz. Feridun M. Emecen, İstanbul 2003. İzzi Süleyman Efendi, İzzî Tarihi, haz. Z. Y1lmazer, İstanbul 2019.

Kesbî Haşim Mehmet Efendi, Ahvâl-ı Anapa ve Çerkes, sad. Mustafa Özsaray, İstanbul 2012.

Kesbî, Divan, İstanbul Üniversitesi Kütüphanesi, nr. TY. 838.

Mehmed Haşim, Mecmua, TSMK, Hazine, nr. 1564. , Seyahatname, İstanbul Millet Ktp. Ali Emiri, Coğrafya, nr.3. , Risale, TSMA, nr. E 12365.

Mustafa Kesbî, İbretnüma-yı Devlet, İstanbul Millet Kütüphanesi, Ali Emiri Ktp. ,Tarih, nr. 484; İstanbul Üniversitesi Kütüphanesi Yazma Eserler, nr. TY. 5943; Topkapı Sarayı Müzesi Kütüphanesi, Hazine, nr. 1572 .

İbretnümâ-yı Devlet (Tahlil ve Tenkitli Metin), haz. Ahmet Öğreten, Ankara 2002.

Müstakimzâde Süleyman, Tuhfe-i Hattâtîn, nşr. İbnülemin Mahmud Kemal, İstanbul 1928.

Orhonlu, Cengiz, “Osmanlı Teşkilatına Aid Küçük Bir Risâle: Risâle-i Terceme”, TTK Belgeler, IV/7-8 (Ankara 1967), s. 39-47.

Osmanlığlu, Serkan, Mustafa Kesbî’nin 1768-1774 Harbi Vekayii, Marmara Üniversitesi Türkiyat Araştırmaları Enstitüsü, İstanbul 2017.

Öğreten, Ahmet, “Kesbî Mustafa Efendi”, DİA, XXV, 306-307.

Özcan, Ahmet, Kethüda Said Efendi Tarihi ve Değerlendirmesi, Kırıkkale Üniversitesi, Yüksek Lisans Tezi, 1999.

Özkaya, Yücel, “Canikli Ali Paşa'nın Risâlesi: Tedâbirü'l-Gazavât”, Tarih Araştırmaları Dergisi, VII/12-13 (1969), s. 120-191.

Rif’at Osman, Edirne Rehnümâsı 863-1327 Seneleri, Edirne 1336.

Schmidt, Jan, “Mehmed Hâşim Efendi’s Memorandum (Mecmu'a) on Circassia of 1213 (1798-9): Contents, Style, Textual, History and a Hitherto Unknown Autograph Kept in the Library of Leiden University", Osmanlı Araştırmaları, XXVI (2005), 413-479.

Şahin, İlhan, "XVIII. Yüzyılın Sonlarına Ait Bir Seyahatname ve Osmanlı Rumelisi”, International Congress of Turkish Studies 18th CIEPO Symposium'da sunulan bildiri.

- Feridun M. Emecen, "XVIII. Yüzyılın Sonlarında Bir Osmanlı Seyyahının Kocaeli Yöresi ile İlgili Tesbit ve Gözlemleri”, Uluslararası Karamürsel Alp ve Kocaeli Tarihi Sempozyumu, Bildiriler, II, 2016, s. 511-515. 
Uluçay, Çağatay, 18. ve 19. Yüzyıllarda Saruhan'da Eşkiyalık ve Halk Hareketleri, İstanbul 1957.

Uzunçarş11, İsmail H., "Tosyalı Ebubekir Râtib Efendi”, Belleten, XXXIX/153 (1975), s. 49-76. , Osmanlı Devleti'nin Merkez ve Bahriye Teşkilatı, Ankara 1984.

Vak'anüvis Hâkim Efendi Tarihi, haz. Tahir Güngör, Marmara Üniversitesi Sosyal Bilimler Enstitüsü, İstanbul 2014.

Vak’anüvis Halil Nuri Bey, Nûrî Tarihi, haz. Seyyid V. Toprak, Ankara 2015.

Yağc1, Zübeyde Güneş, Ferah Ali Paşa’nın Soğucak Muhafızlı̆̆ı (1781-1785), Ondokuz Mayıs Üniversitesi, Doktora Tezi, Samsun 1998.

Yeşil, Fatih, Aydınlanma Çağında Bir Osmanlı Kâtibi: Ebubekir Râtib Efendi, (1750-1799), İstanbul 2011. 
